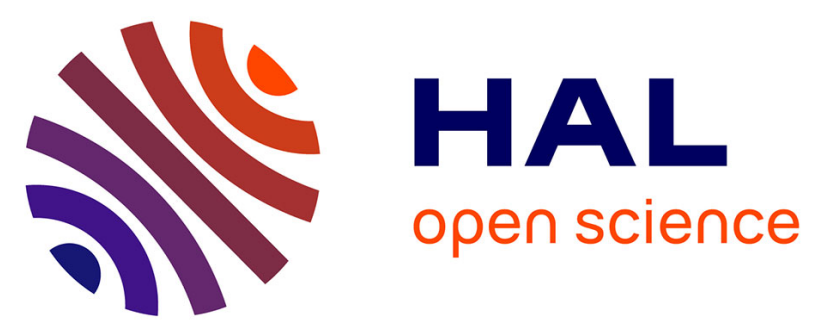

\title{
Faunal assemblages of benthic megainvertebrates inhabiting sea scallop grounds from eastern Georges Bank, in relation to environmental factors.
} Gérard Thouzeau, Ginette Robert, Raoul Ugarte

\section{- To cite this version:}

Gérard Thouzeau, Ginette Robert, Raoul Ugarte. Faunal assemblages of benthic megainvertebrates inhabiting sea scallop grounds from eastern Georges Bank, in relation to environmental factors.. Marine Ecology Progress Series, 1991, 74 (1), pp.61-82. 10.3354/meps074061 . hal-03100811

\section{HAL Id: hal-03100811 \\ https://hal.univ-brest.fr/hal-03100811}

Submitted on 4 Sep 2021

HAL is a multi-disciplinary open access archive for the deposit and dissemination of scientific research documents, whether they are published or not. The documents may come from teaching and research institutions in France or abroad, or from public or private research centers.
L'archive ouverte pluridisciplinaire HAL, est destinée au dépôt et à la diffusion de documents scientifiques de niveau recherche, publiés ou non, émanant des établissements d'enseignement et de recherche français ou étrangers, des laboratoires publics ou privés.

\section{(c)(1)}

Distributed under a Creative Commons Attribution| 4.0 International License 


\title{
Faunal assemblages of benthic megainvertebrates inhabiting sea scallop grounds from eastern Georges Bank, in relation to environmental factors
}

\author{
G. Thouzeau, G. Robert, R. Ugarte \\ Department of Fisheries and Oceans - Halifax Fisheries Research laboratory - PO Box 550, Halifax, Nova Scotia, \\ Canada B3J 2S7
}

\begin{abstract}
Faunal assemblages of benthic megainvertebrates from Georges Bank (NW Atlantic) commercial scallop beds were defined from video-monitored sled-dredge samples. The distribution, diversity, abundance, and biomass of the megafauna were studied in relation to water depth and sediment types. A total of 140 species of megainvertebrates representing 10 phyla were identified, from which epibenthic taxa accounted for ca $76 \%$. Molluscs, crustaceans, annelids, and echinoderms were best represented, with bivalves ranking first in abundance $(55 \%)$ and biomass $(86 \%)$. Significant changes of species diversity, total abundance, and total biomass were found according to sediment type, but not according to depth (except for total biomass). No clear bathymetric pattern was observed, although the mean number of species, mean total density (below $80 \mathrm{~m}$ ), and mean total biomass (below $60 \mathrm{~m}$ ) decreased with increasing depth in the deepest zone. Maximum megafaunal richness was found in biogenic bottoms while minimum value occurred in sand dunes. Total biomass and total density were consistently dominated by a small number of taxa. Three bivalve species (Spisula solidissima, Arctica islandica, Placopecten magellanicus) made up to $71 \%$ of total biomass overall, while 14 species (predominantly Anomia spp., Arctica islandica, and Ophiopholis aculeata) accounted for $70 \%$ of total density. Six megafaunal associations related to 2 major assemblages (biogenic sand-gravel and sandshell fauna) were defined from multivariate analyses. Sediment type, tidal current speed, turbulent mixing, and food availability appear to be the major distribution-regulating factors of the megabenthos in the 55 to $105 \mathrm{~m}$ depth range. Density-dependent predator-prey relationships were the main biological associations shown by megainvertebrates.
\end{abstract}

\section{INTRODUCTION}

Extensive benthic faunal studies have been carried out in recent years on the northeastern continental shelf of North America (Wigley \& Haynes 1958, Wigley 1960, 1961b, 1965, 1968, Wigley \& Theroux 1965, 1981, Williams \& Wigley 1977. Maurer \& Leathem 1980, 1981a, b, Dickinson \& Wigley 1981, Franz et al. 1981, Maurer 1983, Michael et al. 1983, Theroux \& Wigley 1983, Maurer \& Wigley 1984, Maciolek \& Grassle 1987, Michael 1987, Steimle 1987, Theroux \& Grosslein 1987. Wildish et al. 1989), because of the interest in present or potential effects of expanded fisheries, oil and gas drilling, mineral recovery, and ocean dumping (see Grosslein et al. 1979) on benthic organisms. In particular, the benthos is highly sensitive to bioaccumulation of contaminants (trace metals, hydrocarbons) discharged in the course of oil and gas drilling (see Neff
1987 for review), and its diversity and abundance constitute a measure of the health of the ecosystem.

Benthic invertebrates also play a critical role in trophic relationships on the shelf, providing a major source of energy to economically and ecologically important groundfish (Cohen et al. 1982). On Georges Bank, the benthos contributes directly and indirectly to highly productive fisheries of shellfish (scallop) and bottom-feeding fishes such as haddock, cod, and various flounders (Wigley 1965, Edwards \& Bowman 1979, Grosslein et al. 1979, Steimle 1987). In addition, benthic organisms play a supporting role in nutrient exchange, providing a mechanism for flux of nutrients initially trapped in sediments to the water column (Zeitzschel 1980).

Despite the number of comprehensive studies dealing with benthos from Georges Bank, no study has specifically featured the megabenthos (organisms 
retained on a $10 \mathrm{~mm}$ mesh sieve; Hily 1989). Moreover, most benthic faunal surveys were conducted with grab samplers $10.1 \mathrm{~m}^{2}$ Smith/Mclntyre grab; $0.56 \mathrm{~m}^{2}$ Campbell grab; 0.04 and $0.1 \mathrm{~m}^{2}$ modified Van Veen grab) providing small sample sizes, even with replicates at each station. Grab samplers do not give quantitative estimates of the abundance of low-density species, particularly of epibenthic megafauna (Holme 1971, McIntyre 1971, Ogden 1980, Frontier 1983, Caddy \& Carter 1984, Watson et al. 1984). Moreover, most of the mobile species, such as pectinids and decapod crustaceans, escape the grabs (Holme 1971, Maurer \& Wigley 1984, Steimle 1987. Thouzeau 1989), because such bottom-samplers trigger an avoidance response when approaching the seabed.

Camera and video transects have been used to estimate the abundance of megabenthic epifauna on the Northwest Atlantic continental shelf, slope, and rise (Caddy 1970, Cummins 1971, Maciolek et al. 1987, Langton \& Robinson 1990), and in the Bay of Fundy (Caddy 1976, Caddy \& Carter 1984). None of these studies were carried out on the Canadian side of Georges Bank. Such techniques preclude information on most infaunal taxa and only allow identification and counting of epifaunal individuals over 20 to $50 \mathrm{~mm}$ in size on photographs (Dare 1987, Langton \& Robinson 1990) and $40 \mathrm{~mm}$ on video pictures (Franklin et al. 1980).

The present study investigates the distribution of benthic megainvertebrates on Canadian Georges Bank scallop (Placopecten magellanicus Gmelin) grounds, and patterns of megafaunal zonation with depth and sediment types. This investigation is part of a program dealing with benthic pre-recruitment patterns in $P$. magellanicus from the Bank (Thouzeau et al. in press). Environmental factors generate strong variability in sea scallop year-class strength (Mohn et al. 1988), and biotic interactions (spatial and trophic competition, predation) are likely to regulate the survival or growth of benthic organisms, especially pre-recruits (post-larvae and juveniles). This study focuses on large-size (>10 mm) organisms, some of which may present biotic interactions with sea scallops, in order to define the spatial variability of the trophic niche occupied by scallops.

\section{MATERIALS AND METHODS}

Technique and sampling design. Field work was carried out from the RV 'E. E. Prince' between August

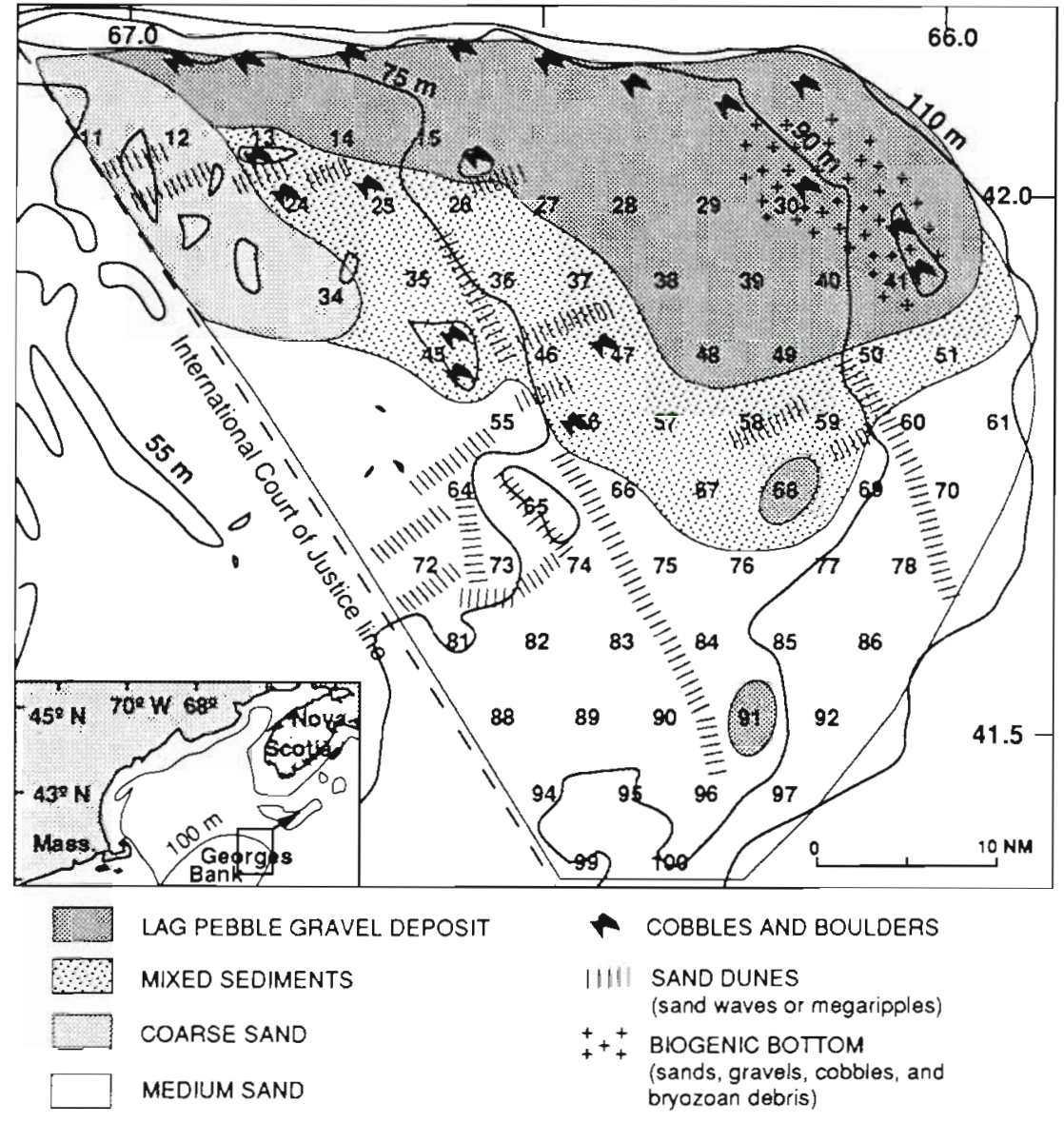

Fig. 1 Location of benthic stations on Georges Bank. Distribution of sediment types mapped according to data from Wigley (1961a), Hulsemann (1967). Schlee \& Pratt (1970), Schlee (1973), Dickinson \& Wigley (1981), Twichell (1983), Theroux \& Grosslein (1987), Twichell et al. (1987), Lough et al. (1989), and Fader (pers. comm.), and from observations of the sediment retained in the collecting box 
23 and 29, 1989, within the area outlined in Fig. 1. The bottom sampling gear used was the AQUAREVE III (Application QUAntitative d'un Rabot Epibenthique avec contrôle Vidéo de l'Echantillonnage), adapted from the technique developed for sampling of Pecten maximus (L.) juveniles (Thouzeau \& Lehay 1988, Thouzeau 1989). The sled-dredge used on Georges Bank collected the upper 5 to $7 \mathrm{~cm}$ of sediment (Thouzeau et al. 1991, Thouzeau \& Vine in press). Operation of the gear was monitored via an underwater video camera allowing control of dredging efficiency. The distance travelled on the bottom was measured by an odometric wheel. The steel collecting box $1.0 \mathrm{~m}$ width $\times 0.4 \mathrm{~m}$ high $\times 1.8 \mathrm{~m}$ depth) was drilled with regularly spaced holes of $10 \mathrm{~mm}$ in diameter. A box closing device adapted from Aldred et al. (1976) was triggered when the sled left the bottom. Once on board, samples were washed, sorted (mechanical sorting table; grid with $10 \mathrm{~mm}$ diameter holes), and preserved in $5 \%$ formaldehyde solution.

The targeted fauna was megabenthic animals retained on a $10 \mathrm{~mm}$ sieve (Hily 1989), including age-1 Placopecten magellanicus. A 2-dimensional systematic lattice sampling scheme was used because little was known about the distribution and behaviour of sea scallop post-larvae and juveniles. Thirteen latitudinal transects spaced $7.4 \mathrm{~km}$ apart (and stations at $8.3 \mathrm{~km}$ intervals) were defined within the $110 \mathrm{~m}$ isobath (Fig. 1). Stations were positioned in alternate rows to maximize the distance between them; this design was selected because it avoids redundancy and information gaps, as may occur with a random sampling design (Frontier 1983). Of 99 potential stations east of the International Court of Justice line (maritime boundary separating the U.S. and Canadian parts of the Bank), operational constraints reduced the coverage to 65 stations (Fig. 1). A total area of $1776 \mathrm{~m}^{2}$ was sampled during the survey. The mean sample size was $25.1 \mathrm{~m}^{2}\left(\mathrm{SD}_{(\mathrm{n}-1)}=9.4 \mathrm{~m}^{2}\right)$, with a range of 11 to $50 \mathrm{~m}^{2}$ according to sediment types.

Data analyses. Organisms were identified to species level for most taxonomic groups (except for hydroids and bryozoans), counted (except for cirripeds), and weighed (wet weight; mollusc shells included).

Samples were standardized to numbers of individuals and $\mathrm{g} \mathrm{m}^{-2}$. Density and biomass isopleths were plotted with the ACON software using Delaunay triangles (see Robert \& Black 1990), and tested for homogeneity of variances using the $F_{\max }$ test (Sokal \& Rohlf 1981). Since the variances were nonhomogeneous for both density and biomass, over the bathymetric and sedimentary gradients studied, a logarithmic transformation $\left(\log _{10}(x+1)\right.$; Sokal \& Rohlf 1981) was applied to the data before further statistical analysis. One-way ANOVA was performed to detect significant changes in species diversity, density and biomass of megainvertebrates, according to depth and sediment types.

Geographic distribution of sediment types (Fig. 1) was mapped according to data from Wigley (1961a), Hulsemann (1967), Schlee \& Pratt (1970), Schlee (1973), Dickinson \& Wigley (1981), Twichell (1983), Twichell et al. (1987), Theroux \& Grosslein (1987), Lough et al. (1989), and Fader (pers. comm.), and from observations of the sediment retained in the collecting box.

Multivariate analyses, specific diversity indices and a dominance index were used to determine megafaunal assemblages and community structure. Hierarchical ascending classification (mean distance criteria; Legendre \& Legendre 1984b) and correspondence analysis (Hill 1974) were performed on transformed density data to determine similarity among samples and spatial patterns of species associations. The Basic programs were adapted from Lebart et al. (1982) and Legendre \& Legendre (1984b), and data processed on an IBM PC computer. Correspondence analysis was preferred over principal component analysis, because of the great number of zeros in the data matrix (Hill 1973, Daget 1976, Gauch et al. 1977). The occurrence and density criteria (Lebart et al. 1982, Legendre \& Legendre 1984b) were used to remove rare (occurrence $<5$ ), low-density species, and undersampled ones (mainly polychaetes), from the initial contingency table (65 stations; 140 species). Stations with very low total abundance $(40,51,59)$ were also removed. Sixtytwo stations and 58 species (see Table 2) were retained.

Shannon-Wiener diversity $H^{\prime}$ and Evenness $J$ (Pielou 1966) were used to define community structure and spatial variability. The Evenness was calculated because the Shannon index varies with sample size (total number of species), prohibiting comparisons between samples (Legendre \& Legendre 1984a). Dominance ranking of the leading species in each faunal assemblage was calculated using the Le Bris index $D^{\prime}$ (Le Bris 1988)

$$
\begin{aligned}
D_{1 j}^{\prime}= & F_{i j} \times D_{i j} \times 100= \\
& {\left[\left(P_{i j} / P_{j}\right) \times 100\right] \times\left[\left(\sum_{k=1}^{P_{i}}\left(N_{i k} / N_{k}\right) \times 100\right) / P_{j}\right] \times 100 }
\end{aligned}
$$

where $P_{i j}=$ number of samples including the species $i$ in the assemblage $j_{i} P_{j}=$ total number of samples in the assemblage $j ; N_{i k}=$ density or biomass of the species $i$ in the $k$ th sample of the assemblage $j ; N_{k}=$ total density or total biomass of the kth sample.

When defining a faunal assemblage, this index is weighted towards species found in high densities or high biomass but only at a few stations (Le Bris 1988). 


\section{RESULTS}

\section{Faunal composition}

A total of 140 species representing 10 phyla (Hydrozoa and Bryozoa undetermined) were identified. Epibenthic species accounted for $76.4 \%$ of the total number of species; polychaetes $(23.1 \%)$, gastropods $(18.5 \%)$, crustaceans $(13.9 \%)$, echinoderms $(12.0 \%)$, poriferans $(7.4 \%)$, ascidians $(7.4 \%)$ and bivalves $(6.5 \%)$ were the main epifaunal taxa collected. Most of the infaunal species were bivalves $(57.6 \%)$ and polychaetes $(24.2 \%)$, and the remainder were amphipods $(6.1 \%)$, nemertean worms $(6.1 \%)$, scaphopods $(3 \%)$ and echinoderms (3\%). Molluscs, crustaceans, echinoderms and annelids were best represented (Table 1), with bivalves prevailing in density and biomass. Epibenthic sessile taxa (Ascidiacea, Porifera, Anthozoa) showed low abundance and biomass, although poriferans and anthozoans were regularly sampled (Table 1).

Total biomass and density were dominated by a small number of taxa: 3 bivalve species, i.e. Spisula solidissima (surf clam). Arctica islandica (ocean quahog) and Placopecten magellanicus made up to $71 \%$ of total biomass, and 14 species (with Anomia spp., Arctica islandica, and Ophiopholis aculeata leading) accounted for $70 \%$ of total density (Table 2).

\section{Geographic distribution of total numbers and total biomass}

The number of species per sample ranged from 4 (Stn 59) to 62 (Stn 30). Total abundance ranged from 0.4 (Stn 59) to 94 ind. $\mathrm{m}^{-2}$ (Stn 30), and total biomass from 4.1 (Stns 36 and 51) to $1038 \mathrm{~g} \mathrm{~m}^{-2}$ (Stn 12). Mean values $( \pm \mathrm{SD})$ were $22.8 \pm 11.3$ species, $10.3 \pm 17.0$ ind. $\mathrm{m}^{-2}$ and $70.5 \pm 145.9 \mathrm{~g} \mathrm{~m}^{-2}$ (Table 1 ).

The highest megabenthos densities (50 to 100 ind. $\mathrm{m}^{-2}$ ) were found in the northeast part of the Bank, with abundance decreasing gradually from east to west along the northem edge (Fig. 2). Two patches in the north and southwest showed intermediate density (15 to 50 ind. $\left.\mathrm{m}^{-2}\right)$, while a low-density area $\left(<5\right.$ ind. $\left.\mathrm{m}^{-2}\right)$ extended over most of the central part of the study area.

The geographic distribution of megabenthos biomass $(y)$ fitted the density $(x)$ distribution (linear regression equation: $y=13.380+2.847 x ; \mathrm{r}=0.85$ for $\mathrm{df}=57$ ), except where low numbers of large-size Spisula solidissima (Stns 11, 12 and 25) or Arctica islandica (Stns 81,82 and 100) generated high biomass (Fig. 3). Highest biomasses ( 200 to $1050 \mathrm{~g} \mathrm{~m}^{-2}$ ) were recorded in the northwest and northeast of the study area. Patches of

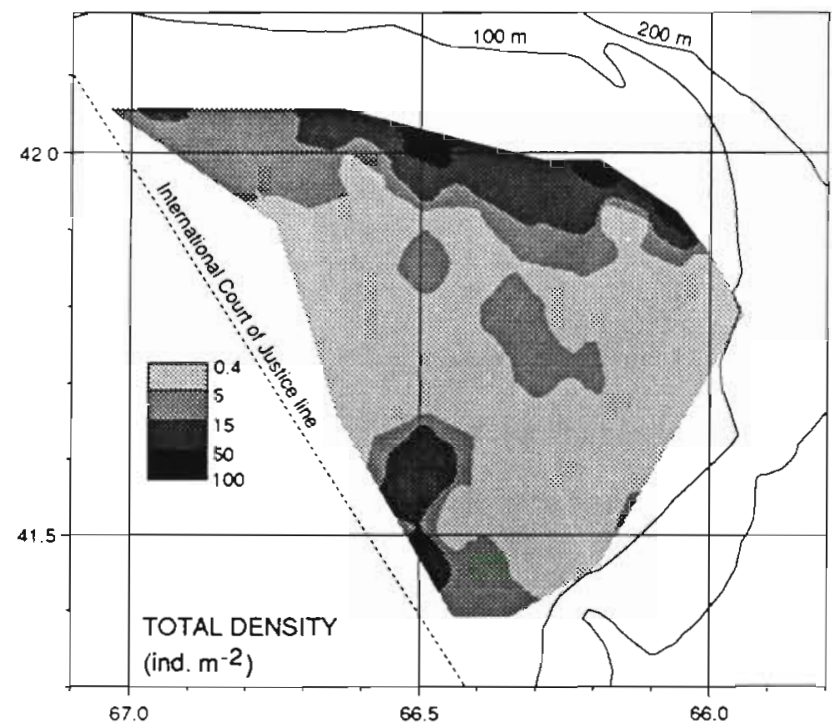

Fig. 2. Geographic distribution of megabenthic invertebrate density (ind. $\mathrm{m}^{-2}$ ) on Georges Bank for all taxonomic groups combined

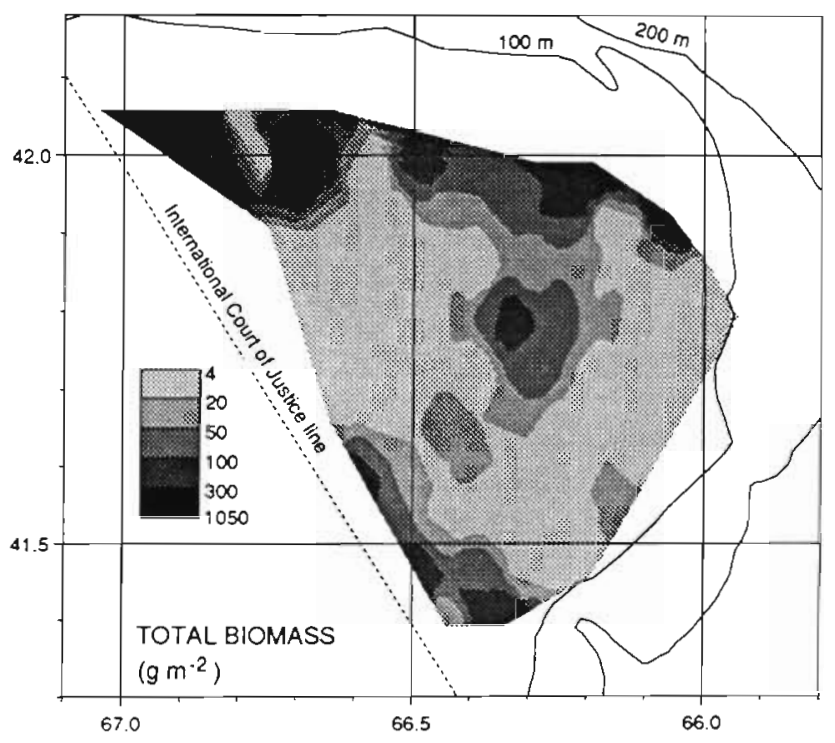

Fig. 3. Geographic distribution of megabenthic invertebrate biomass (wet weight; $\mathrm{g} \mathrm{m}^{-2}$ ) on Georges Bank for all taxonomic groups combined

intermediate biomass (50 to $200 \mathrm{~g} \mathrm{~m}^{-2}$ ) were found in the north and southwest, while the central part showed low biomass $\left(<50 \mathrm{~g} \mathrm{~m}^{-2}\right)$.

\section{Relationship to bathymetry}

Mean number of species did not show significant changes with depth (1-way ANOVA; F-ratio $=0.868$, $p=0.51$ for df $1=5$, df $2=59$ ), as for mean total abundance $(F$-ratio $=1.744, \mathrm{p}=0.139)$. Mean total biomass 
Table 1. Total biomass (wet weight; $\mathrm{g} \mathrm{m}^{-2}$ ), total density (numbers $\mathrm{m}^{-2}$ ), number of species, percentage composition and frequency of occurrence of taxonomic groups of megabenthic invertebrates (except hydroids, bryozoans, and cirripeds) and vertebrates, sampled with the AQUAREVE III on Georges Bank

\begin{tabular}{|c|c|c|c|c|c|c|c|}
\hline \multirow[t]{2}{*}{ Taxa } & \multicolumn{2}{|c|}{ Biomass } & \multicolumn{2}{|c|}{ Density } & \multicolumn{2}{|c|}{ No. of species } & \multirow{2}{*}{$\begin{array}{l}\text { Frequency of } \\
\text { occurrence }\end{array}$} \\
\hline & $\mathrm{g} \mathrm{m}^{-2}$ & Freq. $(\%)$ & No. $\mathrm{m}^{-2}$ & Freq. $(\%)$ & No. & Freq. $(\%)$ & \\
\hline Bivalvia & 60.49 & 85.80 & 5.67 & 55.05 & 25 & 17.9 & 100.00 \\
\hline Gastropoda & 2.78 & 3.95 & 0.42 & 4.13 & 20 & 14.3 & 87.69 \\
\hline Scaphopoda & 0.00 & 0.00 & 0.03 & 0.27 & 1 & 0.7 & 18.46 \\
\hline Polyplacophora & 0.00 & 0.00 & 0.00 & 0.00 & 1 & 0.7 & 1.54 \\
\hline Crustacea & 0.97 & 1.37 & 1.10 & 10.69 & 17 & 12.1 & 93.85 \\
\hline Pycnogonida & 0.00 & 0.00 & 0.00 & 0.00 & 1 & 0.7 & 1.54 \\
\hline Echinoidea & 2.52 & 3.57 & 0.46 & 4.43 & 2 & 1.4 & 81.54 \\
\hline Ophiuroidea & 1.33 & 1.89 & 0.90 & 8.71 & 2 & 1.4 & 16.92 \\
\hline Asteroidea & 0.46 & 0.66 & 0.22 & 2.09 & 4 & 2.9 & 66.15 \\
\hline Holothuroidea & 0.13 & 0.18 & 0.04 & 0.37 & 6 & 4.3 & 33.85 \\
\hline Polychaeta & 0.59 & 0.84 & 1.21 & 11.74 & 33 & 23.6 & 90.77 \\
\hline Ascidiacea & 0.22 & 0.31 & 0.08 & 0.76 & 8 & 5.7 & 21.54 \\
\hline Porifera & 0.89 & 1.26 & 0.05 & 0.52 & 8 & 5.7 & 53.85 \\
\hline Anthozoa & 0.09 & 0.13 & 0.08 & 0.81 & 4 & 2.9 & 40.00 \\
\hline Sipuncula & 0.00 & 0.00 & 0.01 & 0.11 & 1 & 0.7 & 10.77 \\
\hline Rhynchocoela & 0.00 & 0.00 & 0.01 & 0.07 & 2 & 1.4 & 13.85 \\
\hline Osteichthyes & 0.03 & 0.04 & 0.03 & 0.25 & 5 & 3.6 & 18.46 \\
\hline Total & 70.46 & 100.00 & 10.30 & 100.00 & 140 & 100.0 & \\
\hline
\end{tabular}

showed significant variations $(F$-ratio $=4.328, \mathrm{p}=$ $0.002)$. No clear bathymetric pattern was observed; the first 2 variables declined with depth below $80 \mathrm{~m}$ (Fig. 4), but were lower at $50-69 \mathrm{~m}$ than at $70-79 \mathrm{~m}$ (differences not significant with a Tukey HSD test; after a Tukey-Kramer adjustment: $p \geq 0.54$ ). Mean total biomass strongly decreased from $50-59$ to $60-69 \mathrm{~m}$ (from 733 to $58 \mathrm{~g} \mathrm{~m}^{-2}$ ), but did not show such variations between 60 and $\left.99 \mathrm{~m} \mathrm{(37} \mathrm{to} 67 \mathrm{~g} \mathrm{~m}^{-2}\right)$. It decreased however in the deepest stations $\left(7 \mathrm{~g} \mathrm{~m}^{-2}\right)$. Biomass variations were not significant between 60 and $109 \mathrm{~m}$ (Tukey HSD test; $\mathrm{p}>0.50$ in pairwise comparisons).

\section{Relationship to bottom sediment type}

Significant variations in the mean number of species, mean total abundance and mean total biomass ( $\mathrm{SAB}$ ) were found according to sediment types (1-way ANOVA; $p<0.01$ ). The biogenic bottoms (admixture of sand, gravel, cobble and tubes of the polychaete Filograna implexa) from the northeast showed highest number of species per sample and highest total density (Fig. 5). Intermediate values were found on gravel (particle size 2 to $15 \mathrm{~mm}$, similar to the scale of Buchanan \& Kain 1971) and medium-to-coarse sands (except sand dunes); lowest values occurred on sand dunes (sand waves and megaripples) and pebbles (15 to $64 \mathrm{~mm}$ particle size) mixed with cobbles (64 to $256 \mathrm{~mm}$ ) and boulders $(>256 \mathrm{~mm}$ ). A different pattern was observed
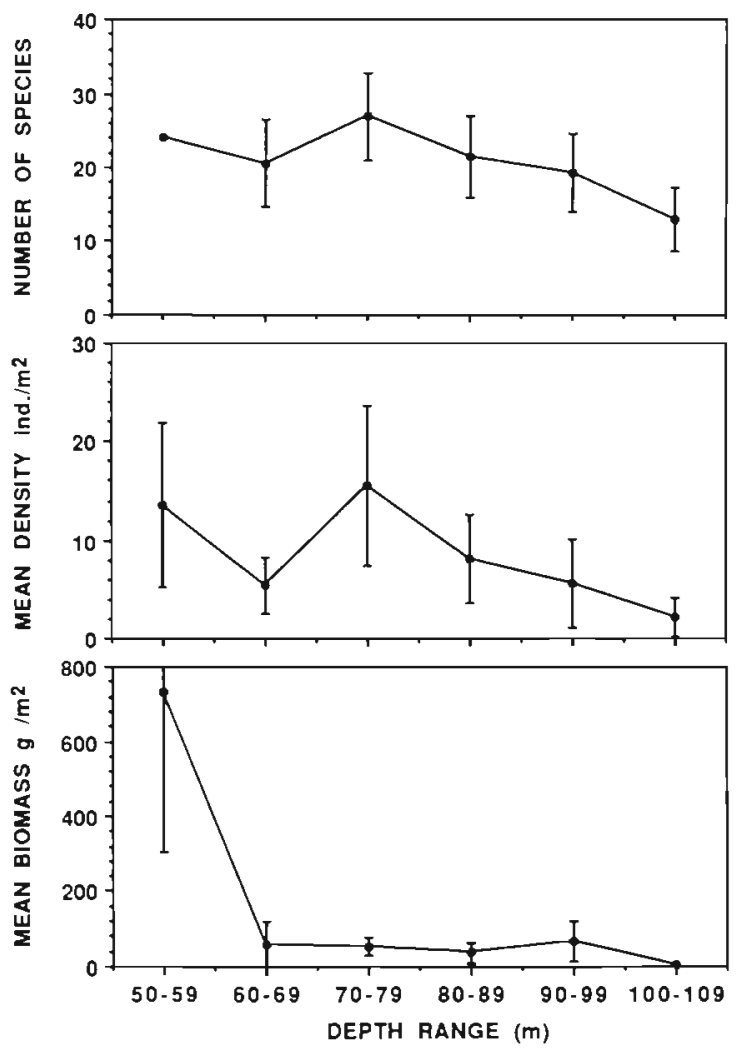

Fig. 4. Mean number of species, mean density (ind. $\mathrm{m}^{-2}$ ), and mean biomass (wet weight; $\mathrm{g} \mathrm{m}^{-2}$ ) of all taxonomic groups of megainvertebrates combined, in relation to depth $(95 \%$ confidence limits are represented) 
Table 2. Rank order of some of the more important species in the taxonomic groups sampled with the AQUAREVE III on Georges Bank, by occurrence, percentage of total biomass, and percentage of total density. Anomia spp. = A. squamula L. and A. simplex Orbigny

\begin{tabular}{|c|c|c|c|c|}
\hline $\begin{array}{l}\text { Phylum } \\
\text { Species }\end{array}$ & Species code & Occurrence & $\begin{array}{c}\text { Total } \\
\text { biomass }(\%)\end{array}$ & $\begin{array}{c}\text { Total } \\
\text { density }(\%)\end{array}$ \\
\hline \multicolumn{5}{|l|}{ Mollusca } \\
\hline Spisula solidissima Dillwyn 1817 & SPS & 35 & 41.57 & 3.96 \\
\hline Arctica islandica Linnaeus 1767 & ARI & 32 & 15.83 & 10.35 \\
\hline Placopecten magellanicus Gmelin 1791 & PLM & 45 & 13.67 & 2.84 \\
\hline Astarte undata Gould 1841 & ASU & 24 & 5.16 & 6.79 \\
\hline Modiolus modiolus L. 1758 & MOM & 9 & 2.57 & 1.38 \\
\hline Astarte crenata subequilatera Sowerby 1854 & ASC & 14 & 2.19 & 1.72 \\
\hline Cyclocardia borealis Conrad 1831 & CYB & 53 & 1.57 & 3.78 \\
\hline Astarte castanea Say 1822 & ASA & 26 & 1.13 & 1.64 \\
\hline Astarte elliptica Brown 1827 & ASE & 22 & 0.78 & 3.71 \\
\hline Astarte borealis Schumacher 1817 & $\mathrm{ASB}$ & 17 & 0.59 & 2.23 \\
\hline Musculus niger Gray 1824 & MUN & 28 & 0.17 & 0.72 \\
\hline Crenella glandula Totten 1834 & CRG & 26 & 0.16 & 3.50 \\
\hline Anomia spp. & ANS & 37 & 0.09 & 10.74 \\
\hline Cerastoderma pinnulatum Conrad 1831 & CEP & 19 & 0.03 & 0.53 \\
\hline Astarte quadrans Gould 1841 & $\mathrm{ASQ}$ & 15 & 0.02 & 0.28 \\
\hline Siliqua costata Say 1822 & SIC & 11 & 0.01 & 0.09 \\
\hline Buccinum undatum L. 1758 & BUU & 41 & 2.15 & 2.51 \\
\hline Colus stimpsoni Mörch 1867 & $\cos$ & 37 & 0.66 & 0.53 \\
\hline Neptunea lyrata decemcostata Say 1826 & NED & 16 & 0.61 & 0.21 \\
\hline Colus pygmaeus Gould 1841 & COP & 16 & 0.02 & 0.16 \\
\hline Crepidula plana Say 1822 & CRP & 12 & 0.01 & 0.11 \\
\hline Dentalium entale L. 1758 & DEE & 12 & 0.01 & 0.27 \\
\hline \multicolumn{5}{|l|}{ Arthropoda: Crustacea: Decapoda } \\
\hline Hyas coarctatus Leach 1815 & $\mathrm{HYC}$ & 42 & 0.56 & 4.89 \\
\hline Pagurus acadianus Benedict 1901 & PAA & 46 & 0.43 & 1.79 \\
\hline Cancer irroratus Say 1817 & CAI & 35 & 0.11 & 0.76 \\
\hline Pagurus pubescens Kroyer 1838 & PAP & 29 & 0.12 & 1.48 \\
\hline Dichelopandalus leptocerus Smith 1881 & DIL & 27 & 0.06 & 0.63 \\
\hline Pagurus arcuatus Squires 1964 & PAR & 24 & 0.04 & 0.52 \\
\hline \multicolumn{5}{|l|}{ Echinodermata } \\
\hline Echinarachnius parma Lamarck 1816 & ECP & 33 & 1.73 & 3.17 \\
\hline Strongylocentrotus droebachiensis Müller 1776 & STD & 30 & 1.85 & 1.26 \\
\hline Asterias vulgaris Verrill 1866 & ASV & 37 & 0.57 & 1.71 \\
\hline Henricia spp. & HES & 15 & 0.02 & 0.23 \\
\hline Ophiopholis aculeata L. 1788 & OPA & 10 & 1.89 & 8.61 \\
\hline Thyone unisemita Stimpson 1851 & THU & 11 & 0.08 & 0.09 \\
\hline \multicolumn{5}{|l|}{ Annelida: Polychaeta } \\
\hline Aphrodite hastata Moore 1905 & $\mathrm{APH}$ & 22 & 0.36 & 0.21 \\
\hline Nereis zonata Malmgren 1867 & NEZ & 30 & 0.09 & 2.41 \\
\hline Potamilla reniformis Leukart 1849 & POR & 35 & 0.07 & 2.96 \\
\hline Lumbrinereis fragilis Muller 1776 & LUF & 45 & 0.05 & 1.15 \\
\hline Nephtys caeca Fabricius 1780 & NEC & 29 & 0.03 & 0.63 \\
\hline Thelepus cincinnatus Fabricius 1780 & THC & 12 & 0.05 & 0.78 \\
\hline Clymenella torquata Leidy 1855 & CLT & 18 & 0.01 & 0.69 \\
\hline Euchone rubrocincta Sars 1861 & EUR & 9 & 0.02 & 0.94 \\
\hline Harmothoe imbricata L. 1767 & HAI & 8 & 0.01 & 0.36 \\
\hline \multicolumn{5}{|l|}{ Chordata: Ascidiacea } \\
\hline Boltenia ovifera L. 1767 & $\mathrm{BOO}$ & 9 & 0.14 & 0.32 \\
\hline Boltenia echinata L. 1767 & $\mathrm{BOE}$ & 8 & 0.01 & 0.20 \\
\hline \multicolumn{5}{|l|}{ Porifera } \\
\hline Haliclona oculata L. 1759 & $\mathrm{HAO}$ & 8 & 0.73 & 0.07 \\
\hline Polymastia robusta Bowerbank 1860 & $\mathrm{POO}$ & 20 & 0.24 & 0.21 \\
\hline Halichondria panicea Pallas 1766 & HAA & 16 & 0.18 & 0.15 \\
\hline \multicolumn{5}{|l|}{ Cnidaria: Anthozoa } \\
\hline Actinothoe gracillima McMurrich 1887 & $\mathrm{ACG}$ & 18 & 0.07 & 0.50 \\
\hline Epizoanthus incrustatus Verrill 1864 & EPI & 12 & 0.05 & 0.29 \\
\hline
\end{tabular}



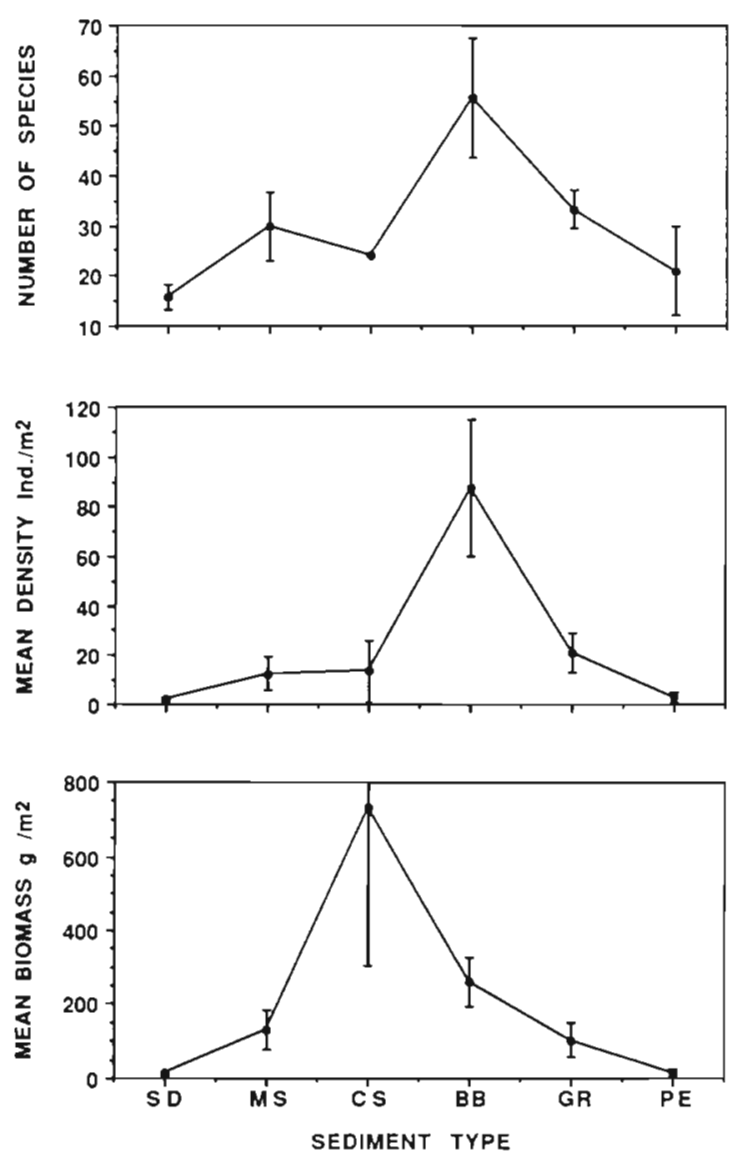

Fig. 5. Mean number of species, mean density (ind. $\mathrm{m}^{-2}$ ), and mean biomass (wet weight: $\mathrm{g} \mathrm{m}^{-2}$ ) of all taxonomic groups of megainvertebrates combined, in relation to sediment type ( $95 \%$ confidence limits are represented). SD = sand dunes; $\mathrm{MS}=$ medium sand; $\mathrm{CS}=$ coarse sand; $\mathrm{BB}=$ biogenic bottom; $G R=$ gravel; $P E=$ pebbles mixed with cobbles and boulders

for biomass; coarse sand $(0.5$ to $2.0 \mathrm{~mm})$ sustained the highest mean biomass $\left(733 \mathrm{~g} \mathrm{~m}^{-2}\right.$; Fig. 5), which showed decreasing trends with particle size $\left(260 \mathrm{~g} \mathrm{~m}^{-2}\right.$ in biogenic bottoms; $103 \mathrm{~g} \mathrm{~m}^{-2}$ in gravel; $15 \mathrm{~g} \mathrm{~m}^{-2}$ in pebbles). Medium sand (0.25 to $0.50 \mathrm{~mm}$ ) of the southern half of the Bank showed high biomass variations (13 to $130 \mathrm{~g} \mathrm{~m}^{-2}$ ), depending on the presence of sand dunes and the amount of shell debris in surficial sediments.

\section{Depth- and sediment-related distribution of dominant taxa}

\section{Bathymetric distribution}

Molluscs prevailed in terms of density in all depth ranges except 100-109 m (polychaetes; Fig. 6), and showed decreased relative abundance with increas- ing depth $(61$ to $78 \%$ of total numbers at $50-79 \mathrm{~m}$; $42 \%$ at $80-99 \mathrm{~m} ; 20 \%$ below $100 \mathrm{~m}$ ). Highest mean densities ( 10 to 12 ind. $\mathrm{m}^{-2}$ ) were found in the 50-59 and $70-79 \mathrm{~m}$ depth ranges. Crustaceans were mainly distributed between 60 and $89 \mathrm{~m}\left(0.9\right.$ to 1.5 ind. $\left.\mathrm{m}^{-2}\right)$, accounting for $17 \%$ of total density at $60-69 \mathrm{~m}$ and $10 \%$ below $70 \mathrm{~m}$. Echinoderms were more abundant at $80-89 \mathrm{~m}\left(31 \%\right.$ of the numbers; 2.6 ind. $\mathrm{m}^{-2}$ ). Polychaetes did not show great variations (1.1 to 1.7 ind. $\mathrm{m}^{-2}$ ) except in the $60-69 \mathrm{~m}$ depth range 10.6 ind. $\mathrm{m}^{-2}$ ). This taxon accounted for $14 \%$ of total density above $90 \mathrm{~m}, 30 \%$ at $90-99 \mathrm{~m}$, and $63 \%$ below $100 \mathrm{~m}$

Molluscs dominated biomass at all depths $(\geq 77 \%$ of total biomass). Highest mean biomass $\left(729 \mathrm{~g} \mathrm{~m}^{-2}\right.$ due to Spisula solidissima) was found in shallower waters (Fig. 6), decreasing with depth except at $90-99 \mathrm{~m}\left(61 \mathrm{~g} \mathrm{~m}^{-2}\right.$ due to Arctica islandica). Mean biomass of crustaceans sharply decreased below $100 \mathrm{~m}$ (from between 1.0 and 1.3 to $0.1 \mathrm{~g} \mathrm{~m}^{-2}$ ), as for echinoderms (higher biomass from 70 to $90 \mathrm{~m}$ ), poriferans and anthozoans. Polychaetes showed decreasing biomass with increasing depth (from 1.3 to $0.4 \mathrm{~g} \mathrm{~m}^{-2}$ ) throughout the 50 to $105 \mathrm{~m}$ depth range.

\section{Relationship to sediment type}

Highest values of density were found on biogenic bottoms and lowest values in pebbles and sand dunes (extremes of sediment texture), for all taxa (Fig. 7). Molluscs prevailed in all sediment types (43 to $78 \%$ of total numbers); mean density ranged from between 1 and 2 to 38 ind. $\mathrm{m}^{-2}$ (Astarte spp. dominant on biogenic bottoms). Crustaceans (5 to $14 \%$ of numbers; 0.3 to 9 ind. $\mathrm{m}^{-2}$ ) showed lowest abundances on the finest sediments. Echinoderms accounted for $35 \%$ of total density on biogenic bottoms (30 ind. $\mathrm{m}^{-2}$; mainly Ophiopholis aculeata), $17 \%$ on sand-shell (2.2 ind. $\mathrm{m}^{-2}$; mainly Echinarachnius parma), and $7 \%$ on gravel (1.4 ind. $\mathrm{m}^{-2}$; mainly Strongylocentrotus droebachiensis and Asterias vulgaris). Polychaetes ( 8 to $24 \%$ of total density; 0.3 to 9 ind. $\mathrm{m}^{-2}$ ), although 3 times more numerous on biogenic bottoms, showed higher relative abundance on sand-shell

All taxa, except molluscs, showed maximum biomass on biogenic bottoms (Fig. 7). Molluscs dominated biomass in all sediment types (70 to $99.5 \%$ of total biomass), despite sharp decreases in the finest and coarsest sediments. Echinoderms (0.9 to $47.4 \mathrm{~g} \mathrm{~m}^{-2}$ ) showed minimum biomass in pebbles, while molluscs (10 to $729 \mathrm{~g} \mathrm{~m}^{-2}$ ), crustaceans $\left(0.2\right.$ to $7.4 \mathrm{~g} \mathrm{~m}^{-2}$ ), polychaetes $\left(0.3\right.$ to $\left.3.2 \mathrm{~g} \mathrm{~m}^{-2}\right)$, poriferans $(0.3$ to $17.6 \mathrm{~g}$ $\left.\mathrm{m}^{-2}\right)$, and ascidians $\left(0.1\right.$ to $\left.1.8 \mathrm{~g} \mathrm{~m}^{-2}\right)$ exhibited lowest values in sand dunes. 

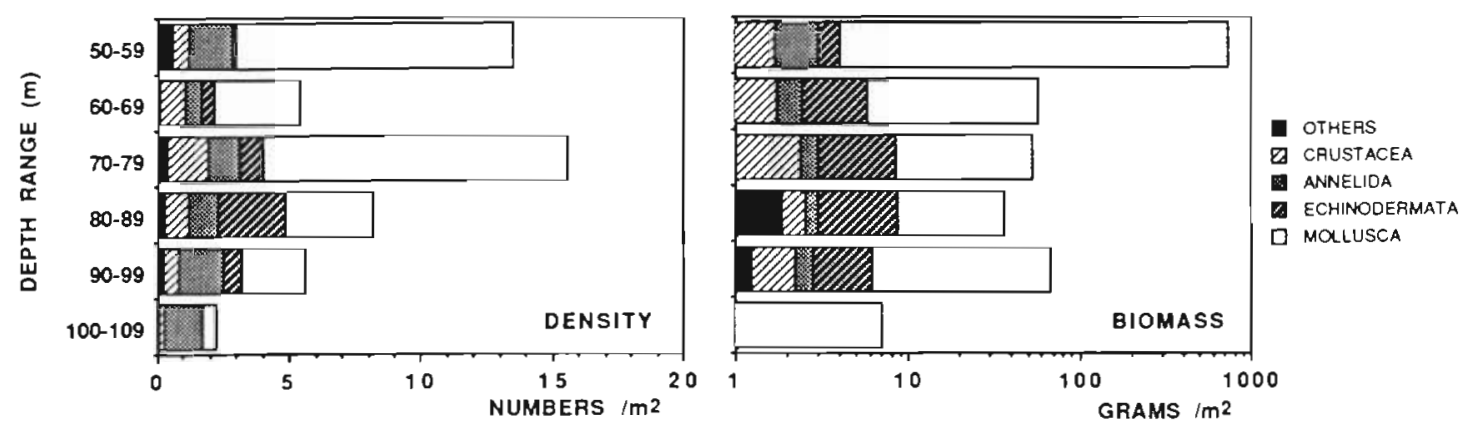

Fig. 6. Mean density (ind. $\mathrm{m}^{-2}$ ), and mean biomass (wet weight; $\mathrm{g} \mathrm{m}^{-2}$ ) of the major taxonomic groups of megainvertebrates, in relation to depth range $(\mathrm{m})$
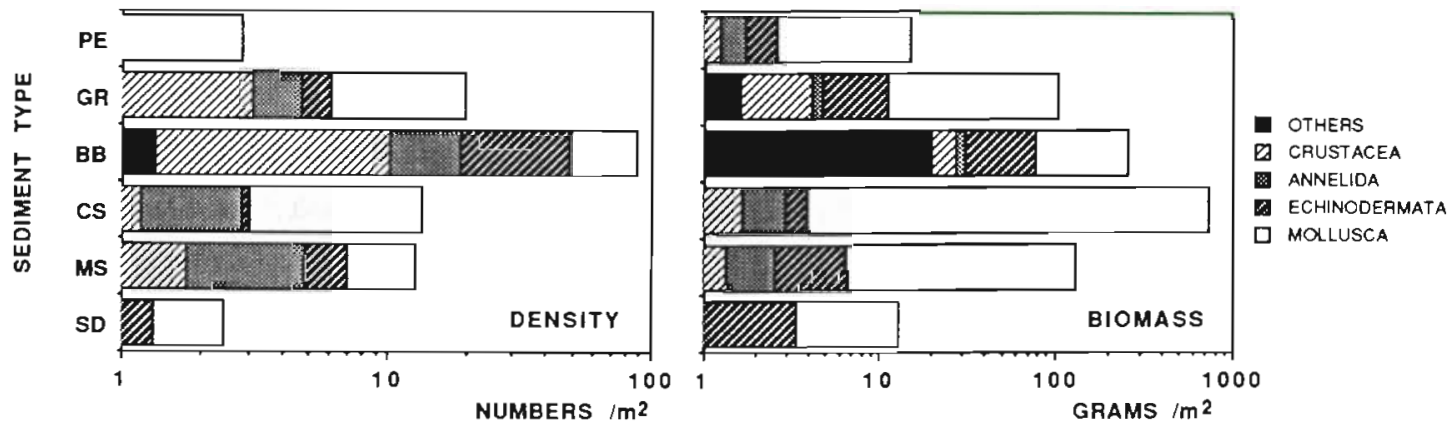

Fig. 7. Mean density (ind. $\mathrm{m}^{-2}$ ), and mean biomass (wet weight; $\mathrm{g} \mathrm{m}^{-2}$ ) of the major taxonomic groups of megainvertebrates, in relation to sediment type. $\mathrm{SD}=$ sand dunes $\mathrm{MS}=$ medium sand $_{\mathrm{C}} \mathrm{CS}=$ coarse sand $\mathrm{BB}=$ biogenic bottom $_{i} \mathrm{GR}=\mathrm{gravel} ; \mathrm{PE}=$ pebbles mixed with cobbles and boulders

\section{Faunal assemblages defined by multivariate analyses}

Hierarchical ascending classification (HAC) on stations

Three major clusters and 2 isolated points (Stns $61 \&$ 77) were separated by the automatic hierarchical classification (Fig. 8). The analysis opposes the finest sediments against the coarsest ones, along a sedimentary gradient from medium sand to pebbles and boulders.

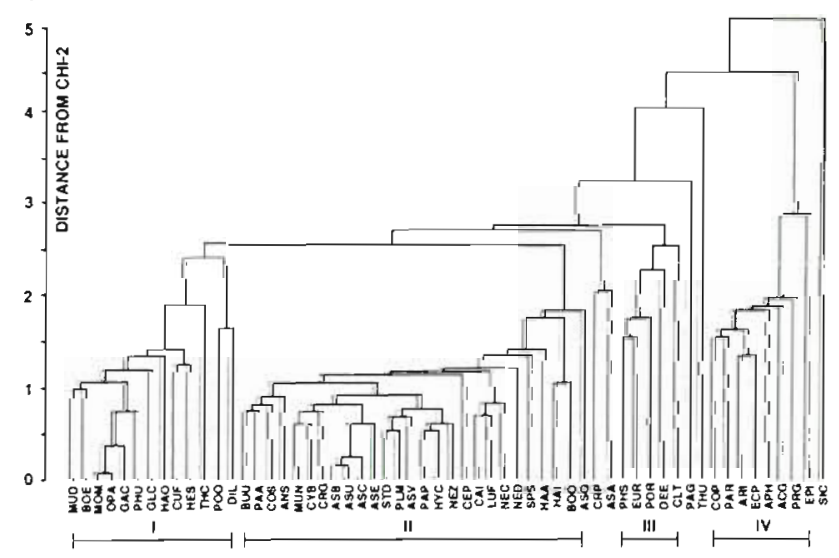

Fig. 8. Stations clustered by hierarchical ascending classification (HAC) using the mean distance criteria. Dendrogram of similarity based on log-transformed $\left(\log _{10}(x+1)\right)$ density values of the 58 most common megabenthic taxa at 62 stations. Three major clusters of stations (I to III) are separated by HAC, with 2 groups (A \& B) isolated within Cluster III
Group I contains central-western stations (including sand dume locations) mainly defined by medium sand with little shell debris. Low total abundance (1.2 to 3.8 ind. $\mathrm{m}^{-2}$ ) and biomass ( 4 to $28 \mathrm{~g} \mathrm{~m}^{-2}$ ) were found in these samples. Group II includes southernmost and eastern (deep water) stations (sand-shell bottoms). The southwestern area (Stns 81, 82, 88, 94), which showed high abundance and biomass, is isolated within the group. All the coarse sediment stations of the northern half define Group III. Group IIIA (northern points) includes most of the gravel and biogenic bottom stations, while Group IIIB refers to heterogeneous sediments (sand mixed with pebbles, cobbles, or boulders). According to another $\mathrm{HAC}$, including all the stations and 87 species, Stns 40,51 and 59 belong to Groups IIIA, II and III, respectively.

Hierarchical ascending classification on species

Four major clusters (species code in Table 2) and 3 isolated points (PAG, THU, SIC) were separated by the classification analysis (Fig. 9), along the sedimentary gradient.

Group I contains epifaunal species (filter feeders or predators) mainly sampled on gravel and biogenic bottoms from the northeastern area (species defining Group IIIA of HAC on stations). Group II (largest unit) 


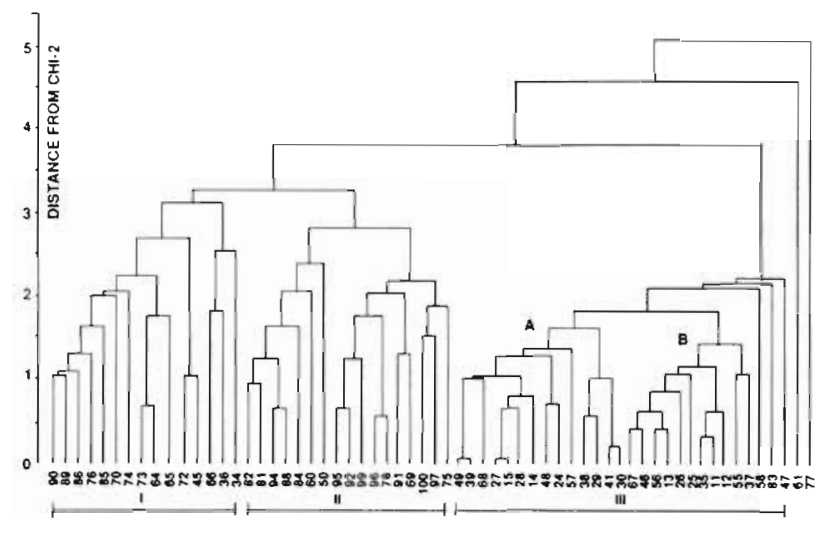

Fig. 9. Species clustered by hierarchical ascending classification (HAC) using the mean distance criteria. Dendrogram of similarity based on $\log$-transformed $\left(\log _{10}(x+1)\right)$ density values of the 58 most common taxa at 62 stations. Species codes in Table 2 except for CUF = Cucumaria frondosa; $\mathrm{GAC}=$ Gattyana cirrosa; GLC = Glycera capitata MUD = Musculus discors; $\mathrm{PAG}=$ Pandora gouldiana; $\mathrm{PHS}=$ Phascolion strombi $;$ PHU $=$ Pholis gunnellus $;$ and $\mathrm{PRG}=$ Propebela gouldii. Four major clusters of species (I to IV) are separated by HAC

includes ubiquitous species (according to sediment type) found on most of the coarse and mixed bottoms of the Bank. Infaunal bivalves (Astarte spp., Cyclocardia borealis, Cerastoderma pinnulatum, Spisula solidissima) show up in this group, as the sandy (coarse sand) fraction increases. Placopecten magellanicus belongs to this group and is closely associated to Asterias vulgaris, Pagurus pubescens and Hyas coarctatus which are potential predators. Group II contains most potential predators of scallops; Cancer irroratus, Crossaster papposus, Pagurus acadianus, Buccinum undatum, Colus stimpsoni and Neptunea lyrata decemcostata are also in this group, while Leptasterias tenera and Cancer borealis are located in deeper waters. Carnivorous polychaetes (Nereis zonata, Nephtys caeca, Harmothoe imbricata), which may prey on scallop spat, also belong to this group. All the other species (except Strongylocentrotus droebachiensis) are filter feeders and trophic competitors of the giant scallop.

Transition to sand-shell bottoms of the southern half is made with Crepidula plana and Astarte castanea, the latter being mainly distributed in sand dunes. Group III contains filter- and deposit-feeding species (Dentalium entale, Phascolion strombi, polychaetes), mainly located at the deepest southern stations. Group IV includes common species of the southern half of the study area (Arctica islandica, Echinarachnius parma, Actinothoe gracillima, Epizoanthus incrustatus, Pagurus arcuatus etc.). Siliqua costata (segregated from all the other species) was mainly distributed in the southsouthwest area of the study. Undersampling may have caused its position on the dendrogram.

\section{Correspondence analysis}

The first 2 axes are the main contributors to total inertia (Table 3), since percentage relative difference is maximum between Axes 2 and 3 (Benzecri \& Benzecri 1984).

Axis 1: the 2 groups of variables isolated by Axis 1 account for $78 \%$ of total variance on the axis for stations, and $86 \%$ of total variance for species. The first axis sets the southern half of the Bank (Group B) against the northeastern area $(A)$, along increasingly coarser sediments (Fig. 10). Stns 30 and 41 (biogenic bottoms) strongly influence Axis 1 definition (29\% of total variance). Ophiopholis aculeata, Astarte undata, A. elliptica, A borealis, A. crenata subequilatera, and Modiolus modiolus are major contributors to total variance for species $(29 \%)$. The negative part of the axis is mostly defined by Stns 88, 94, 100, 74, and 81 (20\% of total variance), and Echinarachnius parma and Arctica islandica ( $28 \%$ of total variance).

Axis 2: the 2 groups of variables (C and D) account for $76 \%$ of total variance on the axis for stations, and $91 \%$ of total variance for species (Fig. 10). The second axis sets the deepest southern (except 61) points (C) against the shallowest stations of the northwest (D), with a decreasing depth gradient along the axis. Arctica islandica, Euchone rubrocincta and Potamilla reniformis prevail in the deepest waters (29\% of total variance), while Spisula solidissima, Anomia spp. (coarse and mixed bottoms), and Astarte castanea (sand dunes) define the axis in shallow waters (34\% of total variance). Placopecten magellanicus (Group D) contributes to the definition of Axis 2, showing preferential distributions for water depths less than $85 \mathrm{~m}$. Previous analysis showed that Leptasterias tenera and

Table 3. Axes contributions to total inertia of correspondence analysis performed on $\log$-transformed $\left(\log _{10}(x+1)\right)$ density data. Sixty-two stations and 58 species were retained for the analysis (see Table 2)

\begin{tabular}{|lcccccccccccc}
\hline Axis no. & 1 & 2 & 3 & 4 & 5 & & 6 & 7 & 8 \\
\hline $\begin{array}{l}\text { Percentage of total inertia } \\
\text { Relative difference }\end{array}$ & 20.65 & 14.45 & 9.46 & 8.16 & 4.47 & 3.97 & 3.59 & 3.44 \\
\hline
\end{tabular}


Cancer borealis were exclusive to Group C. Several variables (32\%) defining Axis 2 were not characteristic of the axis, suggesting that water depth was not the main distribution factor of the megabenthos; the bathymetric gradient would be superposed on a sedimentary gradient.

Axis 3: the 2 groups of variables ( $E$ and $F$ ) account for $87 \%$ of total variance on the axis for stations and $90 \%$ of total variance for species. A strong 'Guttman' distribution (Guttman 1941, Benzecri 1973) of the variables is observed between Axes 1 and 3 (Fig. 11), indicating linked distributions between axes. The third axis sets the sand-gravel stations located on both sides of the northeastern corner (E) against sand dunes (F). Placopecten

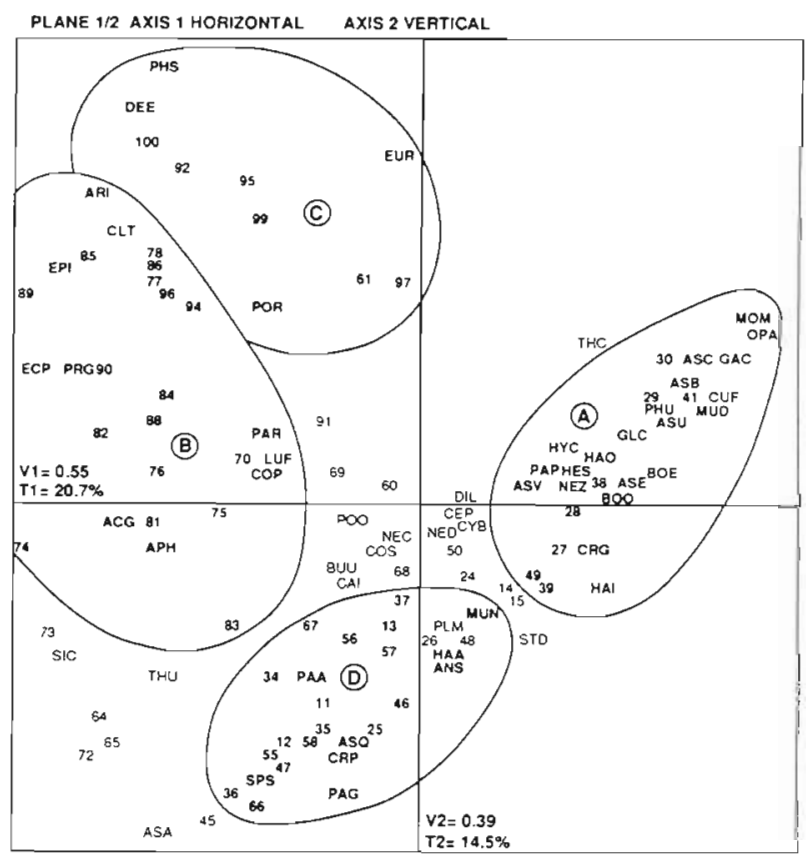

Fig. 10. Plane 1-2 of the correspondence analysis performed on $\log$-transformed $\left(\log _{10}(x+1)\right)$ density values of the 58 most common megabenthic taxa at 62 stations (see Table 2 and Fig. 9 for species codes). Eigen value (V) and percentage of total variance $(T)$ are given for each axis magellanicus, Strongylocentrotus droebachiensis, Dichelopandalus leptocerus, Cancer irroratus, and Colus stimpsoni are characteristic of the sand-gravel stations (maximum relative contributions). Astarte castanea, Siliqua costata, Thyone unisemita, and Echinarachnius parma (11.5\% of total variance on the axis) are the main species associated with sand dunes.

\section{Community structure}

Structural variables of the faunal groups defined by multivariate analyses (Table 4) set the sand dune fauna against the biogenic bottom fauna, in terms of $\mathrm{SAB}$ values. High values of Shannon-Wiener diversity and

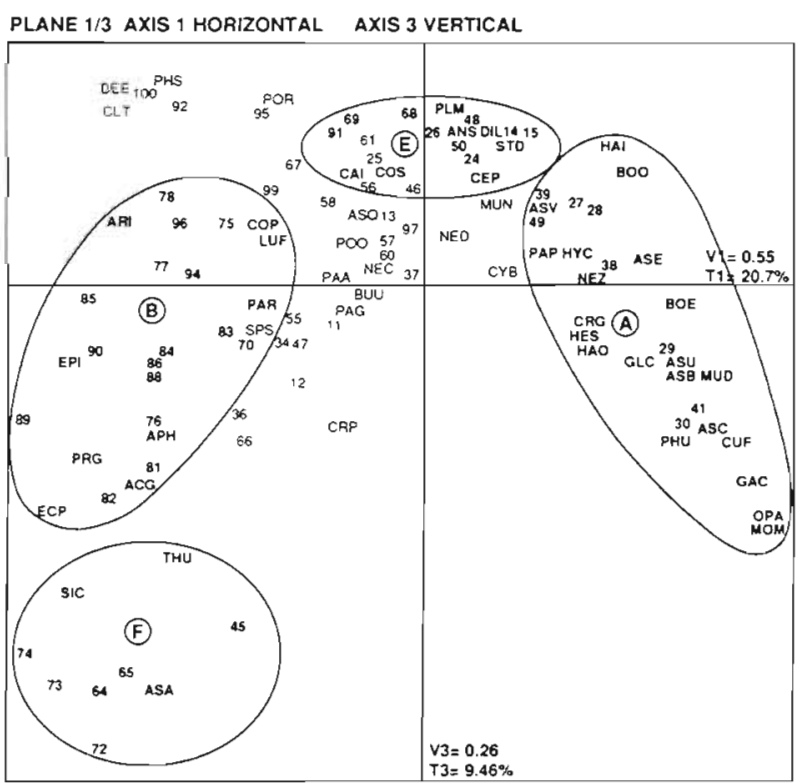

Fig. 11. Plane $1-3$ of the correspondence analysis performed on log-transformed $\left(\log _{10}(x+1)\right)$ density values of the 58 most common megabenthic taxa at 62 stations (see Table 2 and Fig. 9 for species codes). Eigen value (V) and percentage of total variance $(T)$ are given for each axis

Table 4. Synthetic parameters of the megafaunal groups defined by correspondence analysis. $\mathrm{A}=$ biogenic $g r a v e l ; \mathrm{B}=$ sandshell; $C=$ deep sand-shell; $D=$ mixed sediments: $E=$ sand-gravel; $F=$ sand dunes

\begin{tabular}{|c|c|c|c|c|c|c|c|c|}
\hline $\begin{array}{l}\text { Faunal } \\
\text { group }\end{array}$ & $\begin{array}{l}\text { Total area } \\
\text { sampled } \\
\left(\mathrm{m}^{2}\right)\end{array}$ & $\begin{array}{c}\text { Mean sample } \\
\text { size } \\
\left(\mathrm{m}^{2}\right)\end{array}$ & $\begin{array}{c}\text { Species } \\
\text { nchness }\end{array}$ & $\begin{array}{l}\text { Mean no. of } \\
\text { species per } \\
\text { sample }\end{array}$ & $\begin{array}{c}\text { Total } \\
\text { density } \\
\text { (ind. } \mathrm{m}^{-2} \text { ) }\end{array}$ & $\begin{array}{c}\text { Total } \\
\text { biomass } \\
\left(9 \mathrm{~m}^{-2}\right)\end{array}$ & $\begin{array}{c}\text { Shannon } \\
\text { Wiener } \\
\text { diversity }\end{array}$ & Evenness \\
\hline A & 141 & $15.6 \pm 4.3$ & 94 & $38.8 \pm 12.7$ & 40.1 & 123.6 & 4.46 & 0.68 \\
\hline B & 567 & $27.0 \pm 4.5$ & 72 & $20.8 \pm 8.4$ & 5.6 & 31.5 & 3.02 & 0.49 \\
\hline C & 169 & $24.1 \pm 7.8$ & 59 & $22.0 \pm 8.0$ & 5.0 & 39.6 & 3.70 & 0.63 \\
\hline $\mathrm{D}$ & 338 & $21.1 \pm 9.6$ & 68 & $20.1 \pm 8.1$ & 4.7 & 94.1 & 4.29 & 0.71 \\
\hline$E$ & 214 & $21.4 \pm 7.3$ & 79 & $22.9 \pm 9.7$ & 8.6 & 32.9 & 4.02 & 0.64 \\
\hline $\mathrm{F}$ & 209 & $29.9 \pm 3.9$ & 37 & $12.7 \pm 3.4$ & 2.2 & 13.8 & 3.28 & 0.63 \\
\hline
\end{tabular}


Table 5. Dominance ranking in density (Le Bris index $D_{i j}^{\prime}$ Le Bris 1988) of the top 5 species of megainvertebrates in each faunal group defined by correspondence analysis $(\mathrm{A}=$ biogenic gravel; $\mathrm{B}=$ sand-shell; $\mathrm{C}=$ deep sand-shell; $\mathrm{D}=$ mixed sediments; $\mathrm{E}=$ sand-gravel; $F=$ sand dunes). Mean density (ind. $\mathrm{m}^{-2} \pm$ standard error), percentage of total density, and frequency of occurrence of the species are given in each group. Groups A, D, and E define the biogenic sand-gravel assemblage; Groups B. C, and F define the sand-shell assemblage

\begin{tabular}{|c|c|c|c|c|c|}
\hline $\begin{array}{l}\text { Faunal } \\
\text { group }\end{array}$ & Species & $\begin{array}{l}\text { Mean density } \\
\text { (ind. } \mathrm{m}^{-2} \pm \text { SE) }\end{array}$ & $\begin{array}{l}\% \text { of total } \\
\text { density }\end{array}$ & $\begin{array}{l}\text { Freq. }(\%) \text { of } \\
\text { occurrence }\end{array}$ & $\begin{array}{l}\text { Le Bris } \\
\text { index }\end{array}$ \\
\hline A & $\begin{array}{l}\text { Ophiopholis aculeata } \\
\text { Astarte undata } \\
\text { Hyas coarctatus } \\
\text { Anomia spp. } \\
\text { Astarte elliptica }\end{array}$ & $\begin{array}{l}6.38 \pm 12.20 \\
4.84 \pm 5.58 \\
2.76 \pm 2.49 \\
3.07 \pm 5.80 \\
2.51 \pm 2.43\end{array}$ & $\begin{array}{r}17.09 \\
12.96 \\
7.39 \\
8.24 \\
6.72\end{array}$ & $\begin{array}{r}77.8 \\
100.0 \\
100.0 \\
77.8 \\
88.9\end{array}$ & $\begin{array}{r}1329 \\
1296 \\
739 \\
641 \\
597\end{array}$ \\
\hline D & $\begin{array}{l}\text { Spisula solidissima } \\
\text { Anomia spp. } \\
\text { Cyclocardia borealis } \\
\text { Astarte castanea } \\
\text { Placopecten magellanicus }\end{array}$ & $\begin{array}{l}1.32 \pm 1.61 \\
0.72 \pm 1.02 \\
0.33 \pm 0.70 \\
0.33 \pm 0.58 \\
0.25 \pm 0.25\end{array}$ & $\begin{array}{r}24.85 \\
13.53 \\
6.15 \\
6.21 \\
4.71\end{array}$ & $\begin{array}{r}100.0 \\
68.8 \\
87.5 \\
68.8 \\
87.5\end{array}$ & $\begin{array}{r}2485 \\
930 \\
538 \\
427 \\
412\end{array}$ \\
\hline$E$ & $\begin{array}{l}\text { Anomia spp. } \\
\text { Placopecten magellanicus } \\
\text { Hyas coarctatus } \\
\text { Pagurus acadianus } \\
\text { Cyclocardia borealis }\end{array}$ & $\begin{array}{l}2.94 \pm 5.78 \\
0.55 \pm 0.47 \\
0.43 \pm 0.73 \\
0.28 \pm 0.27 \\
0.22 \pm 0.19\end{array}$ & $\begin{array}{r}38.56 \\
7.16 \\
5.63 \\
3.69 \\
2.91\end{array}$ & $\begin{array}{l}70.0 \\
80.0 \\
80.0 \\
80.0 \\
90.0\end{array}$ & $\begin{array}{r}2699 \\
573 \\
450 \\
295 \\
262\end{array}$ \\
\hline B & $\begin{array}{l}\text { Arctica islandica } \\
\text { Echinarachnius parma } \\
\text { Buccinum undatum } \\
\text { Pagurus acadianus } \\
\text { Actinothoe gracillima }\end{array}$ & $\begin{array}{l}3.73 \pm 10.25 \\
0.99 \pm 1.41 \\
0.33 \pm 0.65 \\
0.13 \pm 0.20 \\
0.12 \pm 0.16\end{array}$ & $\begin{array}{r}53.18 \\
14.16 \\
4.72 \\
1.88 \\
1.76\end{array}$ & $\begin{array}{r}93.8 \\
100.0 \\
43.8 \\
68.8 \\
62.5\end{array}$ & $\begin{array}{r}4986 \\
1416 \\
207 \\
129 \\
110\end{array}$ \\
\hline $\mathrm{C}$ & $\begin{array}{l}\text { Potamilla reniformis } \\
\text { Arctica islandica } \\
\text { Clymenella torquata } \\
\text { Euchone rubrocincta } \\
\text { Lumbrinereis fragilis }\end{array}$ & $\begin{array}{l}1.72 \pm 1.37 \\
1.22 \pm 0.96 \\
0.33 \pm 0.64 \\
0.37 \pm 0.40 \\
0.24 \pm 0.18\end{array}$ & $\begin{array}{r}30.24 \\
21.47 \\
5.86 \\
6.54 \\
4.12\end{array}$ & $\begin{array}{r}100.0 \\
100.0 \\
71.4 \\
57.1 \\
85.7\end{array}$ & $\begin{array}{r}3024 \\
2147 \\
419 \\
374 \\
353\end{array}$ \\
\hline F & $\begin{array}{l}\text { Astarte castanea } \\
\text { Echinarachnius parma } \\
\text { Spisula solidissima } \\
\text { Pagurus acadianus } \\
\text { Buccinum undatum }\end{array}$ & $\begin{array}{l}0.78 \pm 0.60 \\
0.57 \pm 0.48 \\
0.18 \pm 0.09 \\
0.18 \pm 0.22 \\
0.07 \pm 0.06\end{array}$ & $\begin{array}{r}34.41 \\
25.43 \\
8.10 \\
8.28 \\
3.01\end{array}$ & $\begin{array}{r}100.0 \\
83.3 \\
100.0 \\
66.7 \\
83.3\end{array}$ & $\begin{array}{r}3441 \\
2119 \\
810 \\
552 \\
251\end{array}$ \\
\hline
\end{tabular}

Evenness (when referring to Frontier 1983) in coarse sediments of the northern half of the Bank (Groups A and $D$ ) indicate a well-diversified megafauna. Minimal values in sand-shell of the southern half (B) emphasize the dominance of Arctica islandica and Echinarachnius parma (53 and $14 \%$ of total density, respectively) on these bottoms.

Dominance ranking of the leading species (Tables 5 \& 6) shows that each assemblage is dominated by a small number of species, the top 10 species accounting for 73 to $86 \%$ of mean total density and 84 to $98 \%$ of mean total biomass. Moreover, 1 or 2 species (particularly Arctica islandica, Potamilla reniformis, Astarte castanea or Echinarachnius parma) make up 52 to $60 \%$ of mean total density in the southern half. One or two species also dominate the biomass, except for the northeastern area (A). A. islandica predominates in sand-shell (62 to $91 \%$ of total biomass); E. parma and A. castanea are the leading species in sand dunes (48 and $31 \%$ of total biomass, respectively). Placopecten magellanicus $156 \%$ of total biomass in sand-gravel) and Spisula solidissima ( $84 \%$ of total biomass in coarse sand) are the dominant taxa in the northern half. P. magellanicus is a major component of each assemblage (except for the sand dunes), being ranked in the top 15 of all density indices, and first (Group E) or second in biomass.

\section{DISCUSSION}

\section{Species richness of megabenthos}

A moderate number of species was collected with the AQUAREVE sampler compared to previous studies on Georges Bank. The NorthEast Fisheries Center (NEFC) reference list comprises 259 benthic species (Theroux \& 
Table 6. Dominance ranking in biomass (Le Bris index $D_{i j}^{\prime}$ Le Bris 1988) of the top 5 species of megainvertebrates in each faunal group defined by correspondence analysis $(\mathrm{A}=$ biogenic gravel $\mathrm{B}=$ sand-shell $\mathrm{C}=$ deep sand-shell; $\mathrm{D}=$ mixed sediments; $\mathrm{E}=$ sand-gravel; $F=$ sand dunes). Mean biomass ( $\mathrm{g} \mathrm{m}{ }^{2} \pm$ standard error), percentage of total biomass, and frequency of occurrence of the species are given in each group. Groups $A, D$, and $E$ define the biogenic sand-gravel assemblage; Groups $B, C$, and $F$ define the sand-shell assemblage

\begin{tabular}{|c|c|c|c|c|c|}
\hline $\begin{array}{l}\text { Faunal } \\
\text { group }\end{array}$ & Species & $\begin{array}{l}\text { Mean biomass } \\
\left(\mathrm{g} \mathrm{m}^{-2} \pm \mathrm{SE}\right)\end{array}$ & $\begin{array}{l}\% \text { of total } \\
\text { biomass }\end{array}$ & $\begin{array}{l}\text { Freq. }(\%) \text { of } \\
\text { occurrence }\end{array}$ & $\begin{array}{l}\text { Le Bris } \\
\text { index }\end{array}$ \\
\hline \multirow[t]{5}{*}{$\mathrm{A}$} & Astarte undata & $24.88 \pm 28.50$ & 21.83 & 100.0 & 2183 \\
\hline & Placopecten magellanicus & $21.13 \pm 24.33$ & 18.54 & 77.8 & 1442 \\
\hline & Astarte crenata subequilatera & $10.57 \pm 12.83$ & 9.28 & 77.8 & 721 \\
\hline & Ophiopholis aculeata & $9.61 \pm 20.68$ & 8.43 & 77.8 & 656 \\
\hline & Modiolus modiolus & $13.01 \pm 26.09$ & 11.41 & 55.6 & 634 \\
\hline \multirow[t]{5}{*}{$D$} & Spisula solidissima & $115.10 \pm 249.18$ & 83.81 & 100.0 & 8381 \\
\hline & Placopecten magellanicus & $12.71 \pm 12.22$ & 9.25 & 87.5 & 810 \\
\hline & Buccinum undatum & $2.63 \pm 3.53$ & 1.92 & 75.0 & 144 \\
\hline & Strongylocentrotus droebach. & $1.36 \pm 1.65$ & 0.99 & 62.5 & 62 \\
\hline & Astarte castanea & $1.18 \pm 2.57$ & 0.86 & 68.8 & 59 \\
\hline \multirow[t]{5}{*}{ E } & Placopecten magellanicus & $16.56 \pm 17.25$ & 56.41 & 80.0 & 4513 \\
\hline & Strongylocentrotus droebach. & $2.70 \pm 3.78$ & 9.19 & 60.0 & 551 \\
\hline & Buccinum undatum & $1.95 \pm 2.91$ & 6.65 & 80.0 & 532 \\
\hline & Colus stimpsoni & $1.02 \pm 1.20$ & 3.48 & 80.0 & 279 \\
\hline & Pagurus acadianus & $0.66 \pm 0.77$ & 2.26 & 80.0 & 181 \\
\hline \multirow[t]{5}{*}{ B } & Arctica islandica & $22.38 \pm 34.08$ & 62.07 & 94.1 & 5842 \\
\hline & Placopecten magellanicus & $3.36 \pm 4.55$ & 9.33 & 64.7 & 604 \\
\hline & Echinarachnius parma & $2.09 \pm 2.25$ & 5.80 & 100.0 & 580 \\
\hline & Spisula solidissima & $3.36 \pm 9.88$ & 9.33 & 52.9 & 493 \\
\hline & Buccinum undatum & $0.82 \pm 1.41$ & 2.29 & 47.1 & 108 \\
\hline \multirow[t]{5}{*}{$\mathrm{C}$} & Arctica islandica & $47.95 \pm 73.5$ & 91.25 & 100.0 & 9125 \\
\hline & Placopecten magellanicus & $1.50 \pm 1.44$ & 2.86 & 71.4 & 204 \\
\hline & Colus stimpsoni & $0.50 \pm 1.03$ & 0.95 & 57.1 & 54 \\
\hline & Potamilla reniformis & $0.24 \pm 0.23$ & 0.45 & 100.0 & 45 \\
\hline & Echinarachnius parma & $0.27 \pm 0.22$ & 0.52 & 71.4 & 37 \\
\hline \multirow[t]{5}{*}{ F } & Echinarachnius parma & $6.86 \pm 8.67$ & 48.06 & 83.3 & 4005 \\
\hline & Astarte castanea & $4.39 \pm 3.32$ & 30.71 & $: 00.0$ & 3071 \\
\hline & Spisula solidissima & $0.82 \pm 0.66$ & 5.76 & $: 00.0$ & 576 \\
\hline & Pagurus acadianus & $0.31 \pm 0.34$ & 2.17 & 66.7 & 145 \\
\hline & Buccinum undatum & $0.21 \pm 0.19$ & 1.47 & 83.3 & 123 \\
\hline
\end{tabular}

Grosslein 1987), but Michael (1987), Maciolek \& Grassle (1987), and Maciolek et al. (1987) reported greater numbers $(700,783$, and 1019 species, respectively). However, this study reports the greatest number of epifaunal taxa despite the largest sieve mesh size. The prevalence of epifaunal taxa among megainvertebrates collected with the AQUAREVE III (76.4\%) constitutes a major difference to macrofaunal studies. Maciolek \& Grassle (1987) reported only $9.4 \%$ of epifaunal taxa among the 783 species collected with a Van Veen grab. The specificity of the AQUAREVE as a better collector of epibenthic macrofauna compared to grabs (Thouzeau 1989) also applies to the megabenthos; it may partly reside in the greater areas of sampled bottom relative to studies using grabs. The inverse relationship existing between species richness and sieve mesh size on Georges Bank (1019 and 783, 700, 259 , and 160 to 165 species retained on $0.3,0.5,1.0$, and
$10.0 \mathrm{~mm}$, respectively) precludes any quantitative comparisons referring to different sampling methods, as pointed out by Maciolek \& Grassle (1987) and Steimle (1987).

Different sampler types and sieve mesh sizes may explain most of the differences among studies for benthos species richness. However, the absence of several megabenthic taxa in this study may be related to environmental factors such as water depths, bottomwater (b-w) temperatures, and sediment types. This study was limited to depths in the range 55 to $110 \mathrm{~m}$ (commercial scallop grounds), while greater bathymetric ranges (between 60 to 200 and 25 to $250 \mathrm{~m}$ ) were reported in Theroux \& Grosslein (1987). Michael (1987), and Maciolek \& Grassle (1987). Maciolek et al. (1987) sampled a deeper area of the Bank between 250 and $2155 \mathrm{~m}$. The annual range and extremes of $b-w$ temperatures (linked to depth) also present smaller 
variations in the study area. The annual range of $b-w$ temperature varies between 0 to $4{ }^{\circ} \mathrm{C}(100$ to $200 \mathrm{~m}$ depth) and 12 to $16^{\circ} \mathrm{C}$ on top of the Bank (Dickinson \& Wigley 1981, Michael et al. 1983). The magnitude of temperature variations in the study area ranges between 4 to $8^{\circ} \mathrm{C}$ in the mid-east ( 80 to $110 \mathrm{~m}$ depth) and 8 to $12{ }^{\circ} \mathrm{C}$ in the mid-west $(60$ to $80 \mathrm{~m})$. Northwest Atlantic outer shelf boreal species such as Astropecten americanus, Sclerasterias tanneri, Porania insignis (Franz et al. 1981), Catapagurus sharreri, and Munida iris (Theroux \& Grosslein 1987) were not sampled because they occur in deeper waters where winter b-w temperatures remain above 5 to $6{ }^{\circ} \mathrm{C}$. Summer b-w temperatures explain the absence of cold-water species such as Hippasteria phrygiana, Ceramaster granularis, Pteraster militaris (found in areas where $\mathrm{b}$-w temperatures do not exceed 7 to $8^{\circ} \mathrm{C}$; Franz et al. 1981), Pandalus borealis, Lebbeus polaris (Williams \& Wigley 1977), and Cyclopecten pustulosus (Theroux \& Wigley 1983), usually found in waters deeper than 100 to $120 \mathrm{~m}$. On the other hand, the absence or scarcity of major epibenthic species such as Brisaster fragilis, Ophiura sarsi, and Geryon quinquedens (species defining the Western Basin assemblage of Theroux \& Grosslein 1987) may be related to the absence (except for small patches) of fine-grain sediments (silt-clay and muddy sand) in the study area. On Georges Bank, these sediments mainly occur in the Western Basin (northwestern U.S. zone), between 150 and $200 \mathrm{~m}$.

\section{Depth- and sediment-related distribution of taxonomic groups}

Though most of the differences were not significant, the mean number of species, mean total density (below $80 \mathrm{~m}$ ), and mean total biomass (below $60 \mathrm{~m}$ ) decreased with increasing depth in this study (Fig. 4). All taxa showed sharp decreases in density and biomass below $100 \mathrm{~m}$ (Fig. 6), in agreement with Theroux \& Grosslein (1987). The same bathymetric patterns (but high spatial variations), with abrupt faunal discontinuities below $100 \mathrm{~m}$, were found in different locations of the Middle Atlantic Bight region (Wigley \& Theroux 1976, Boesch et al. 1977, Wigley \& Theroux 1981, Maurer \& Wigley 1984) and elsewhere (see Parsons et al. 1977). Recent studies on the Bank (Maciolek \& Grassle 1987, Michael 1987 ) did not show reduced macrofaunal richness and density in deeper waters ( 25 to $200 \mathrm{~m}$ depth range). It may result from polychaete density increasing with depth on Georges Bank (Maurer \& Leathem 1980).

Bathymetric distribution of the megabenthos varied depending on taxa in this study (Fig. 6). Mollusc density decreased with depth below $80 \mathrm{~m}$ on the northern edge of the Bank, which agrees with Theroux \&
Grosslein (1987). Sediment instability (in sand dunes) or inappropriate substrata (pebbles and cobbles) might account for the low bivalve densities in the $60-69 \mathrm{~m}$ depth range (Maurer \& Wigley 1984). The inverse relationship between mollusc biomass and depth (except at $90-99 \mathrm{~m}$ ) agrees with both studies cited above. Patchy distributions of heavy species (Arctica islandica and Spisula solidissima) created spatial variability along the depth gradient however, as in Theroux \& Grosslein (1987). Decapod crustaceans and echinoderms showed the same bathymetric patterns overall, with increasing densities from the shallowest waters to mid-depths (70-79 $\mathrm{m}$ for decapods; $80-89 \mathrm{~m}$ for echinoderms), and decreasing values in deeper waters. The same trend was observed for echinoderm biomass, while there was no clear pattern for decapods except decreased biomass below $100 \mathrm{~m}$. Theroux \& Grosslein (1987) did not find a significant relationship between depth and density or biomass of these taxa. Maurer (1983) found significant decreasing echinoderm biomass with increasing depths, but no relationship for density. Wigley \& Theroux (1981) and Maurer \& Wigley (1984) showed a negative correlation between depth $(0$ to $200 \mathrm{~m}$ depth range) and decapod density or biomass, off southern New England, but the opposite for echinoderms.

Discrepancies between studies may be explained by variations in faunal composition (and dominant species presenting different bathymetric preferences), and patchy distributions of major species. Nonsignificant differences (except for total biomass in shallow water) and great variations of SAB values with depth (Fig. 4) in this study would indicate that depth is not the main factor regulating megabenthos distribution in the 55 to $105 \mathrm{~m}$ depth range. Significant differences and smaller variations with sediment type (Fig. 5), as well as the prevalence of this factor in defining the faunal assemblages, would suggest that sediment type (depending on bottom currents and turbulent mixing) is the main distribution factor of the megabenthos in the study area.

The lowest values of SAB were found at the extremes of sediment texture (Fig. 5). Except for maximum values, similar patterns in abundance and biomass were observed, i.e. decreased values with increased particle size in the coarsest sediments but positive relationship with grain size in sands. Wigley \& Theroux (1981) and Theroux \& Grosslein (1987) also found increased total biomass with grain size in sands. The latter study reported average total biomasses of $371 \mathrm{~g} \mathrm{~m}^{-2}$ in coarse sand, $230 \mathrm{~g} \mathrm{~m}^{-2}$ in medium sand (but less than $50 \mathrm{~g} \mathrm{~m}^{-2}$ on most of the Canadian side of the Bank), and $85 \mathrm{~g}$ $\mathrm{m}^{-2}$ in gravel of the Northeast Peak (neither biogenic bottoms nor pebbles were separated from gravels in their study), Total biomass in AQUAREVE samples was 
consistently higher than in grab samples, which may be explained by the efficiency of the collecting device, preservation techniques, contagious distributions of the species and year-to-year differences.

The escapement of mobile organisms with grab sampling (see 'Introduction') leads to underestimated biomass of large-size taxa (pectinids, decapods) which accounted for $15 \%$ of total biomass in this study (Table 2). Moreover, these taxa could represent up to $61 \%$ of total biomass on coarse sediments (Table 6). The sled-dredge towed at 1 to $1.5 \mathrm{knots}$ is likely to catch greater numbers of these slow-moving individuals, compared to grabs. In addition, the higher biomasses found in the coarse sediments of the Northeast Peak may reflect better sampling with the AQUAREVE, since grabs do not dig deeply in hard bottoms (Holme 1971, McIntyre 1971, Wildish et al. 1989). Preservation techniques may account for some discrepancy between studies since Mills et al. (1982) showed that methods of preservation and storage may alter biomass estimates by as much as $15 \%$. The absence of Spisula solidissima from the dominant taxa of Theroux \& Grosslein (1987), and the scarcity of Echinarachnius parma in this study, also point out to the impact of distribution patterns of dominant species on the results.

The present study emphasizes 2 sediment types (sand dunes and biogenic bottoms) which were not segregated by Theroux \& Grosslein (1987). SAB values of sand dune samples were markedly lower than those found in other medium sand samples (Fig. 5). A 10-fold reduction of total megabenthos density and biomass was found in sand dunes, compared to sand-shell. This result indicates that, despite its size, the megabenthos (both epifauna and infauna) does not appear to be better adapted to sediment instability than the macrobenthos, which shows decreased diversity with increased sediment mobility (Maurer \& Wigley 1984). One should remember however, that factors affecting the settling and survival of juveniles will also determine to a large extent the distributional patterns of the adults, since most of the sampled megafaunal species are poorly motile. Biogenic bottoms were identified as a specific biosedimentary category, because of their richness and particular megafauna (several species were exclusive to this unit). Hulsemann (1967) also distinguished the northeastern corner from the rest of the Bank, because of higher level of calcium carbonate in surface sediments ( $>20 \%$, versus $<5 \%$ ). SAB values in biogenic bottoms were markedly higher than those recorded in gravel (Fig, 5). Moreover, each taxonomic group showed highest density and biomass (except for mollusc biomass) for this bottom type (Fig. 7). Sediment heterogeneity and porosity, as well as the functional importance of polychaete tubes and cobbles (in provid- ing spatial refuges from predators and suitable microhabitats for invertebrates, especially the juveniles), may partly explain biogenic bottom richness. The abundance of infaunal taxa can be ascribed to sediment porosity (polychaetes) and the occurrence of a sandy fraction between biogenic fragments (allowing bivalves to inhabit the sediment). Maurer \& Leathem (1981b) showed that the abundance of motile carnivorous polychaetes on Georges Bank was related to coarse-grained sediments. Enhanced movement and feeding processes within the pore spaces existing between grains would promote their proliferation. This relationship applies to the biogenic bottoms compared to other coarse sediments: motile polychaetes were 3 times more numerous in biogenic bottoms than in coarse sand. The abundance of sessile epibenthic taxa results from the occurrence of numerous substrata (biogenic fragments, gravels, and cobbles) on the surface of the sediment, allowing individuals to settle.

Distribution patterns of the megabenthos were expected to be less obvious than those of macrobenthos, because the former comprises a proportionately higher abundance of vagile epifaunal taxa, which are supposedly less sensitive to sediment texture. Welldefined patterns of megafaunal zonation were found however, pointing out habitat preference and likely functional relationships.

\section{Dominant taxa and functional relationships between species}

Dominant megabenthic taxa of Georges Bank belong to the same major taxonomic groups as the macrobenthos (see Theroux \& Grosslein 1987), i.e. molluscs, echinoderms, crustaceans, and annelids (large-size tubiferous polychaetes). Despite the number of epifaunal species among the megabenthos, low abundances and biomasses of epibenthic sessile taxa were found (Tables 1 \& 2). The sparsity of epifauna on exploited scallop grounds has been pointed out by Caddy (1973), Caddy \& Carter (1984), and Lough et al. (1989). Sediment furrowing, broken epifaunal organisms (worm tubes, poriferans, ascidians, anthozoans), and the absence of erect ectoprocts and hydrozoans result from trawl and scallop dredge activities. This study emphasizes the sparsity of epibenthic sessile taxa on coarse sediments of the northern half of the Bank (heavily fished area), despite numerous substrata available for settlement.

Macrofaunal abundance is dominated by amphipods and polychaetes on the Northwest Atlantic continental shelf (Wigley 1961b, Wigley 1968, Wigley \& Theroux 1976, Boesch et al. 1977, Maurer \& Leathem 1980, Wigley \& Theroux 1981, Michael et al. 1983, Maurer \& Wigley 
1984, Maciolek \& Grassle 1987, Michael 1987, Theroux \& Grosslein 1987). On Georges Bank, these taxa accounted for 45 and $26 \%$ respectively, of total abundance of macro-and megabenthos collected with grab samplers (Theroux \& Grosslein 1987). Similar dominances (60\% amphipods and $20 \%$ polychaetes) were found off southern New England (Maurer \& Wigley 1984).

The present study establishes bivalve prevalence ( 55 and $86 \%$ of total density and biomass, respectively) among megainvertebrates, and emphasizes the leading role of filter-feeding bivalves in the area under investigation (Table 2). Bivalve dominance (57 to $80 \%$ of total biomass) is a recurrent trend in the whole Middle Atlantic Bight region (Wigley \& Theroux 1981, Maurer \& Wigley 1984). The U.S. side of Georges Bank exhibits different patterns with echinoderms and molluscs being co-dominant in biomass (Wigley 1961b, 1968, Theroux \& Grosslein 1987). Echinarachnius parma $(40.9 \%$ of total biomass), Arctica islandica $(25.7 \%)$, and Modiolus modiolus $(8.4 \%)$ were reported as major contributors to biomass while Placopecten magellanicus $(0.1 \%)$, Spisula solidissima, and Astarte spp. were not listed among the dominant taxa (Theroux \& Grosslein 1987). The low abundances of Spisula may indicate undersampling by grabs (as for scallops), this species being commercially exploited on the Bank. Surf clams were mostly sampled in coarse sand in depths less than $70 \mathrm{~m}$ in this study, which agrees with its shallow-water preference (Theroux \& Wigley 1983). The scarcity of Echinarachnius parma (sand dollar) on the Canadian side of the Bank (Table 2) is related to its sedimentary affinity for fine-to-medium, often rippled, sands (Maurer \& Wigley 1984, Lawrence et al. 1985 Maciolek \& Grassle 1987, Theroux \& Grosslein 1987), and its bathymetric preference for shallow waters. Sand dollars are mainly located in the western half of Georges Bank (U.S. side), a large high-biomass area (100 to $4450 \mathrm{~g} \mathrm{~m}^{-2}$ ) extending from 40 to $60 \mathrm{~m}$ (Theroux \& Grosslein 1987).

The largest filter-feeding bivalves (Spisula solidissima, Arctica islandica, Placopecten magellanicus, and Modiolus modiolus) showed discrete distributions in the study area, suggesting limited trophic competition between species, and possibly adaptative strategies. Caddy \& Carter (1984) stated that the distribution of most epifaunal species in relation to other taxa was random; the common presence of most species within a habitat would be determined by physical characteristics of the habitat. However, numerous functional relationships between epifaunal species have been shown in benthic communities (see Ojeda \& Dearborn 1989 for review). In addition to the barnacle-sea scallop association reported by Caddy \& Carter (1984), this study mainly pointed out predator-prey relationships (Fig. 9) such as the close distributions of $P$. magellanicus and
Asterias vulgaris (one of the main sea scallop predators on the Bank); Anomia spp. (prey) and Buccinum undatum, Colus stimpsoni and Pagurus acadianus; $A$. islandica (prey) and Pagurus arcuatus and Colus pygmaeus; A. vulgaris (prey) and Crossaster papposus. The latter, which mainly feeds on asteroids and especially on Asterias (see Franz et al. 1981), showed maximum abundance at the same stations as Asterias (northern half). Bivalve predators (decapods, boring gastropods, echinoderms) exhibited density-dependent relationships with potential preys (Figs. $6 \& 7$ ), suggesting that distribution patterns of motile carnivorous megabenthos depend on trophic relationships. Maximum abundance of sea scallops (northern half) was associated with maximum density of spatio-trophic competitors and potential predators; the areas of high scallop occurrence are also likely to have the greatest mortality rates resulting from biotic interactions.

\section{Faunal assemblages in relation to environmental factors}

The first attempt to identify faunal associations on Georges Bank and in the Gulf of Maine was made by Wigley \& Haynes (1958) who defined 4 communities (I to IV) relating to sand fauna, silty-sand fauna, gravel fauna, and muddy basin fauna. 'Community II' (Northern edge and Northeast Peak) and 'Community III' (extending on most of the bank in depths less than $100 \mathrm{~m}$ ) correspond to the present study area. Theroux \& Grosslein (1987) also recognized 4 major faunal zones, the 'Northeast Peak assemblage' and 'Central Georges assemblage' relating to Communities II and III, respectively. Macrofaunal assemblages emphasize taxa (amphipods, polychaetes) which were missed or undersampled in this study. Based on sediment types and bathymetry however, the megafaunal assemblages (Fig. 12A) clearly match the faunal zones of Theroux \& Grosslein (1987). In addition, the present study allows the definition of small-scale variations (facies) in megafaunal zonation, which are likely to be related to sediment patchiness, bottom currents, turbulent mixing, food availability and depth.

\section{Biogenic sand-gravel assemblage}

The 3 northern facies (A, D, E in Fig. 12A) are part of the 'Northeast Peak assemblage' and exhibit coarse sediment fauna. The biogenic gravel facies ( $\mathrm{A}$; northeastern corner of the Bank; 75 to $91 \mathrm{~m}$ depth) occupies a great variety of coarse sediments from coarse sand to cobbles and boulders, with overlying biogenic fragments; percent gravel by weight is always $>50 \%$ and 

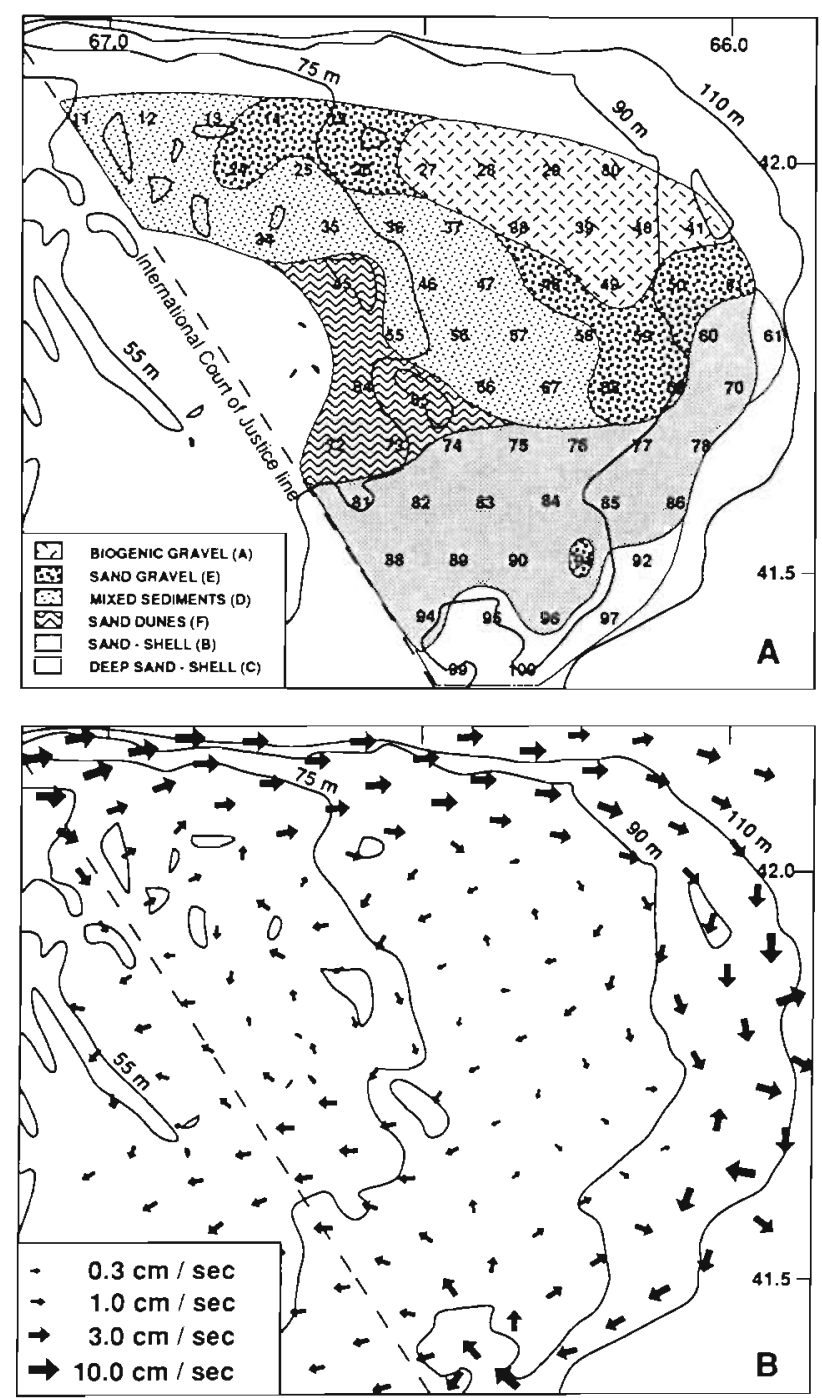

Fig. 12. (A) Geographic location of megafaunal assemblages as outlined by multivariate analyses. Facies $A, D$ and $E$ define the biogenic sand-gravel assemblage while facies $B, C$ and $F$ refer to the sand-shell assemblage. (B) Depth-averaged mean Eulerian current driven by rectification of the $M_{2}$ tidal current in the Georges Bank region as predicted by Greenberg's $7 \mathrm{~km}$ grid, nonlinear numerical model of the Gulf of Maine (Greenberg 1983, modified)

often $>70 \%$ (Lough et al. 1989). Adapted to this bottom type is an abundance of sessile suspension-feeding organisms, i.e. barnacles Balanus hameri, tunicates, poriferans, epifaunal bivalves and tubiferous polychaetes (Table 7). Free-living forms include many suspension-feeding echinoderms and carnivores (decapods, boring gastropods, polychaetes, echinoderms). Members of the megabenthic infauna are mostly smallsize ( $\leq 30 \mathrm{~mm}$ ) bivalves (Table 7 ). Several taxa typical of fine-grain sediments (Nephtys incisa, Musculus discors and Ophiura sarsi; Theroux \& Grosslein 1987) suggest the inclusion of fine particles among the sandy fraction. A number of species are exclusive to the biogenic facies, such as Ophiura sarsi, Chlamys islandica, Hiatella arctica, Natica clausa, Margarites costalis, Calliostoma occidentale, Halocynthia pyriformis, pandalus montagui and Lebbeus groenlandicus. Theroux \& Wigley (1983) and Theroux \& Grosslein (1987) also reported distributions of C. islandica (and Mytilidae) from the northeastern Bank. The biogenic gravel facies from Georges Bank presents similarities (same dominant epifauna) with the inshore (5 to $18 \mathrm{~m}$ ) crustose coralline community of the Gulf of Maine (Ojeda \& Dearborn 1989).

The sand-gravel facies (E) extends on each side of the biogenic facies, on gravels (10 to $69 \%$ of sediment weight), pebbles and cobbles interspersed with sand. The sand-gravel fauna ciffers from the biogenic gravel fauna by decreased abundance and biomass of suspension feeders (epi- and irfauna), the absence of several epibenthic taxa and the advent or increase of mediumsand species common in the southern half (Arctica islandica, Clymenella torquata, Ensis directus, Echinarachnius parma, Astarte castanea, Pagurus arcuatus). Ranking of Dichelopandalus leptocerus in the top 10 of the density index indicates silty-sand or mud patches; this species is characteristic of the 'silty-sand and mud patch fauna' (Wigley 1968, Maurer \& Wigley 1984).

The mixed sand facies (D) occupies a large area extending from the northwest ( 55 to $60 \mathrm{~m}$ ) to the central part $(75$ to $82 \mathrm{~m}$ ) of the study area. Sediments reflect spatial variations of tidal current direction and speed (Fig. 12B) and contain an admixture of coarse sand (dominant fraction) interspersed with boulders and pebbles of different sizes. Percent gravel by weight ranges from less than $10 \%$ in the northwestern area up to $49 \%$ in the central zone (Lough et al. 1989). An increase of sand particles allows the inclusion of new sand-bottom species among the dominant taxa (Spisula solidissima, Astarte castanea, A. quadrans, Aphrodite hastata) and surf clams predominate. Typical mediumsand species also show up in this unit (Thyone spp., Lunatia heros, Siliqua costata, Cerebratulus sp.), or sustain higher abundance than in sand-gravel (Echinarachnius parma, Pandora inornata, Dendrodoa carnea). Hard-bottom epibenthic taxa and infaunal bivalves common to the biogenic gravel and sandgravel facies either show decreased density and biomass (Table 7) or are absent (Polynoidae, Subertechinus hispidus, Boltenia spp.).

The 3 northern facies exhibit marked differences in faunal composition or dominance, which justify their separate identity within the Northeast Peak assemblage of Theroux \& Grosslein (1987). The gravel fauna on the northern edge is one of the richest and most complex benthic communities on Georges Bank (Wig- 
Table 7. Distribution by density intervals (mean values) of the main megabenthic taxa sampled with the AQUAREVE III, within the 6 faunal groups defined by multivariate analyses. $(+)<0.1$ ind. $\mathrm{m}^{-2} ;(++) 0.1$ to 0.9 ind. $\mathrm{m}^{-2} ;(+++) 1.0$ to 4.9 ind. $\mathrm{m}^{-2}$; $(++++) 5.0$ to 9.9 ind $\mathrm{m}^{-2}$

\begin{tabular}{|c|c|c|c|c|c|c|}
\hline $\begin{array}{l}\text { Trophic groups } \\
\text { Species }\end{array}$ & $\begin{array}{c}\text { Biogenic } \\
\text { gravel } \\
\text { (A) }\end{array}$ & $\begin{array}{l}\text { Sand- } \\
\text { gravel } \\
\text { (E) }\end{array}$ & $\begin{array}{l}\text { Mixed } \\
\text { sand } \\
\text { (D) }\end{array}$ & $\begin{array}{l}\text { Sand- } \\
\text { shell } \\
\text { (B) }\end{array}$ & $\begin{array}{l}\text { Deep } \\
\text { facies } \\
\text { (C) }\end{array}$ & $\begin{array}{c}\text { Sand } \\
\text { dunes } \\
\text { (F) }\end{array}$ \\
\hline \multicolumn{7}{|l|}{ Suspension-feeders } \\
\hline Halocynthia pyriformis & + & & & & & \\
\hline Chlamys islandica & + & & & & & \\
\hline Ascidia callosa & + & & & & & \\
\hline Musculus discors & ++ & + & & & & \\
\hline Boltenia echinata & ++ & + & & & & \\
\hline Cucumaria frondosa & ++ & + & + & & & \\
\hline Ophiopholis aculeata & $+++t$ & + & + & + & & \\
\hline Haliclona oculata & + & & + & + & & \\
\hline Boltenia oviferá & ++ & + & & & + & \\
\hline Modiolus modiolus & +++ & + & + & & + & \\
\hline Musculus niger & ++ & ++ & + & + & & \\
\hline Crenella glandula & +++ & + & ++ & & & + \\
\hline Henricia spp. & ++ & + & + & + & & \\
\hline Astarte crenata subequilatera & +++ & + & + & + & + & \\
\hline Astarte borealis & +++ & + & + & + & + & \\
\hline Cerastoderma pinnulatum & ++ & + & + & + & + & \\
\hline Astarte elliptica & +++ & ++ & + & + & + & \\
\hline Placopecten magellanicus & ++ & ++ & ++ & + & + & \\
\hline Halichondria panicea & + & + & + & + & + & \\
\hline Astarte undata & +++ & ++ & + & + & + & + \\
\hline Cyclocardia borealis & +++ & ++ & ++ & + & + & + \\
\hline Anomia spp. & +++ & $+t+$ & ++ & ++ & + & + \\
\hline Astarte quadrans & + & + & + & + & & + \\
\hline Polymastia robusta & + & + & + & + & + & + \\
\hline Potamilla reniformis & ++ & ++ & ++ & + & +++ & + \\
\hline Euchone rubrocincta & ++ & & + & + & ++ & \\
\hline Ensis directus & & + & + & + & & \\
\hline Spisula solidissima & & + & +++ & ++ & & ++ \\
\hline Arctica islandica & & + & + & +++ & +++ & \\
\hline Crepidula plana & & + & + & + & & + \\
\hline Astarte castanea & & + & ++ & + & & ++ \\
\hline Clymenella torquata & & + & + & ++ & ++ & \\
\hline Thracia septentrionalis & & & + & & + & \\
\hline Thyone unisemita & & & + & + & & + \\
\hline Siliqua costata & & & + & + & & + \\
\hline \multicolumn{7}{|c|}{ Carnivores (predators and scavengers) } \\
\hline Natica clausa & + & & & & & \\
\hline Ophiura sarsi & + & & & & + & \\
\hline Cancer borealis & + & & & & + & \\
\hline Harmothoe imbricata & ++ & + & & & & \\
\hline Crossaster papposus & + & + & + & & & \\
\hline Neptunea lyrata decemcostata & + & + & + & + & & \\
\hline Pagurus pubescens & ++ & ++ & + & + & + & \\
\hline Hyas coarctatus & +++ & ++ & + & ++ & ++ & \\
\hline Nephtys caeca & ++ & + & + & + & + & + \\
\hline Asterias vulgaris & ++ & ++ & + & + & + & + \\
\hline Nereis zonata & +++ & ++ & + & + & + & + \\
\hline Cancer irroratus & ++ & ++ & ++ & + & + & + \\
\hline Pagurus acadianus & ++ & ++ & ++ & ++ & + & ++ \\
\hline Buccinum undatum & ++ & ++ & ++ & ++ & + & + \\
\hline Colus stimpsoni & + & ++ & + & + & + & + \\
\hline Pagurus arcuatus & + & + & + & ++ & + & + \\
\hline Lumbrinereis fragilis & ++ & + & ++ & ++ & ++ & + \\
\hline Crangon septemspinosa & & + & + & & & \\
\hline Colus pygmaeus & & + & + & + & + & \\
\hline Actinothoe gracillima & & + & + & ++ & + & + \\
\hline
\end{tabular}


Table 7 (continued)

\begin{tabular}{|c|c|c|c|c|c|c|}
\hline $\begin{array}{l}\text { Trophic groups } \\
\text { Species }\end{array}$ & $\begin{array}{c}\text { Biogenic } \\
\text { gravel } \\
\text { (A) }\end{array}$ & $\begin{array}{l}\text { Sand- } \\
\text { gravel } \\
\text { (E) }\end{array}$ & $\begin{array}{l}\text { Mixed } \\
\text { sand } \\
\text { (D) }\end{array}$ & $\begin{array}{l}\text { Sand- } \\
\text { shell } \\
\text { (B) }\end{array}$ & $\begin{array}{l}\text { Deep } \\
\text { facies } \\
\text { (C) }\end{array}$ & $\begin{array}{c}\text { Sand } \\
\text { dunes } \\
(F)\end{array}$ \\
\hline \multicolumn{7}{|l|}{ Carnivores (predators and scavengers) } \\
\hline Aglaophamus circinata & & + & + & & + & \\
\hline Lunatia heros & & & + & + & & \\
\hline Cerebratulus sp. & & & + & + & + & + \\
\hline Leptasterias tenera & & & & + & + & + \\
\hline Epizoanthus incrustatus & & & & ++ & + & \\
\hline Aporrhais occidentalis & & & & + & + & \\
\hline \multicolumn{7}{|l|}{ Deposit-feeders } \\
\hline Thelepus cincinnatus & ++ & + & & + & ++ & \\
\hline Aphrodite hastata & & + & + & + & + & + \\
\hline Echinarachnius parma & & + & + & +++ & $+t$ & ++ \\
\hline Phascolion strombi & & & & + & + & \\
\hline Dentalium entale & & & & + & ++ & \\
\hline \multicolumn{7}{|l|}{ Omnivores } \\
\hline Dichelopandalus leptocerus & ++ & ++ & + & + & + & \\
\hline Strongylocentrotus droebachiensis ${ }^{\alpha}$ & ++ & ++ & ++ & + & + & + \\
\hline
\end{tabular}

ley \& Haynes 1958, Wigley 1968). Spatial variations of megafaunal diversity and abundance are clearly related to changes in environmental conditions on the Bank. Near-surface $\mathrm{M}_{2}$ semidiurnal tidal current (most energetic component of the current field) increases from $10 \mathrm{~cm} \mathrm{~s}^{-1}$ along the southern flank (200 m depth) to a maximum predicted flow of about $100 \mathrm{~cm} \mathrm{~s}^{-1}$ across the shallow ( $\leq 60 \mathrm{~m}$ ) crest of the Bank (Moody et al. 1984). Modelling of the residual barotropic circulation due to rectification of the $\mathrm{M}_{2}$ tidal current (Fig. 12B; modified from Greenberg 1983) shows strong variations of the depth-averaged Eulerian current speed in the study area. High bottom-current velocities may not allow sessile epibenthic taxa to settle and maintain themselves on the seabed. The greater abundance of sessile epibenthos in the biogenic gravel facies is associated with lower tidal currents (Fig. 12B), compared to the sand-gravel areas. Decreased bottomcurrent speeds and small-scale gyre circulation at Stns 26. 38, and 39 may explain deposition of fine-grain particles in these zones and the presence of silt-clay and muddy sand fauna in the gravel facies.

Dominance of suspension feeders among Georges Bank megafauna $(70 \%$ of total density; $89 \%$ of total biomass) is associated with the highest annual total primary production (265 to $455 \mathrm{~g}$ carbon $\mathrm{m}^{-2}$; in O'Reilly et al. 1987) of the Northwest Atlantic shelf, except for the Middle Atlantic coastal band (Cohen \& Grosslein 1987). Higher abundance of suspension feeders in the northern half of the Bank (Table 7 ) may be related to higher food availability due to physical processes, compared to the southern half. In addition to the clockwise flow around Georges Bank (Greenberg 1983, Butman et al. 1987), a complex frontal system exists along the northern edge of the Bank separating Georges Bank water from Gulf of Maine water (Flagg 1987). The extensive gravel deposit is in a transition area where the subsurface Gulf of Maine-Georges Bank water front moves northward and southward across the Bank edge with the rotary tidal currents (Lough \& Trites 1989). The summer intensification of the front-jet system and the intrusion of cold, nutrient-rich Gulf of Maine Intermediate Water along the northern edge (Lough et al. 1989) lead to maximum abundance of phytoplankton centered near the northern flank during summer (Cura 1987). Distribution of large-size suspension feeders, such as Spisula solidissima, in northwestern shallow waters is associated with a primary production which may be 4 to 5 times greater than at the Bank $100 \mathrm{~m}$ isobath ( $\mathrm{O}^{\prime}$ Reilly et al. 1987). In depths shallower than about $60 \mathrm{~m}$, averaged water-column concentration of chlorophyll a and annual total primary production are $2.58 \mathrm{mg} \mathrm{m}^{-3}$ and $455 \mathrm{~g} \mathrm{C} \mathrm{m}^{-2}$ respectively, compared to $1.18 \mathrm{mg} \mathrm{m}^{-3}$ and $310 \mathrm{~g} \mathrm{C} \mathrm{m}^{-2}$ between 60 and $100 \mathrm{~m}$ (O'Reilly et al. 1987). In addition, tidal currents are strong enough in shallow waters to cause sediment resuspension (Twichell et al. 1987) and complete vertical mixing of the water column throughout the year (Butman \& Beardsley 1987. Flagg 1987), providing live phytoplankton cells and resuspended particulate organic matter (250 to $500 \mu \mathrm{g} \mathrm{l}^{-1}$ in summer; Twichell et al. 1987) to suspension feeders. Decreased primary production from shallow to deep waters does not explain the abundance of suspension feeders in the biogenic gravel facies. This may 
result from higher sedimentation of organic matter (providing food to benthic organisms) because of the low rotary tidal currents in this area, compared to the sandgravel facies.

\section{Sand-shell assemblage}

The 3 southern facies (B, C, F in Fig. 12A) belong to the Central Georges assemblage of Theroux \& Grosslein (1987), and exhibit a sand-shell fauna. Medium sands predominate in the southern half but numerous valves of ocean quahogs, surf clams and sea scallops, near and on top of the sediment, provide a substratum to sessile polychaetes and Zoantharia.

The typical fauna of the sand-shell assemblage (B) extends on most of the southern half of the study area, from 75 to $90 \mathrm{~m}$. Arctica islandica and Echinarachnius parma are the leading species. Actinothoe gracillima, Epizoanthus incrustatus, Pagurus arcuatus, Spisula solidissima, Clymenella torquata, Aphrodite hastata, Dentalium entale, Phascolion strombi, and Cerebratulus sp. are other typical components. Free-living forms include most of the carnivorous decapods, gastropods and asteroids found in the northern assemblage (ubiquitous), but in lower densities. Motile carnivorous polychaetes are reduced to Nephtyidae and Nereidae; sessile epibenthic taxa also show lower diversity and abundance than in the northern assemblage (Table 7). The sand-shell fauna presents similarities with the sand fauna off southern New England (Maurer \& Wigley 1984); it contains more deposit feeders (feeding on the benthic boundary layer) than the coarse sediment assemblage. It also includes fewer suspension-feeding infaunal bivalves than coarse sands of the northwest. Differences may result from lower food availability (suspended particles) in southern waters (Cura 1987), which do not benefit from the intrusion of nutrient-rich subsurface Gulf of Maine water. Water stratification (preventing particulate organic matter resuspension) and lower sedimentation of organic matter resulting from lower initial phytoplankton biomass and decreased productivity with depth (O'Reilly et al. 1987) may explain the scarcity of large-size suspension feeders in the eastern half of the sand-shell assemblage. Higher abundances of $A$. islandica and $S$. solidissima in the western half may be related to higher dinoflagellate abundance (see Cura 1987) and increased tidal currents (Fig. 12B). Surf clams and ocean quahogs were both sampled in areas (Stns 11, 12, 81, 88, 94, 95 \& 100) presenting some of the highest bottom currents within the study area.

The deep-water sand-shell facies (C) is located in the southernmost deepest zone ( 90 to $105 \mathrm{~m}$ ) of the study area, but it probably extends northwards on sand-shell bottoms in waters deeper than 90 to $95 \mathrm{~m}$ (e.g. Stn 61). Tubiferous and motile polychaetes predominate, which agrees with the depth-related distribution of annelids on the Bank (Maurer \& Leathem 1980). Heterogeneous megafauna includes an admixture of coarse-sediment and sand-shell species (Table 7). Increased abundances of small-size suspension-feeding polychaetes (in contrast to large-size bivalves) in this deep facies may result from the smaller size of primary producers in deep waters. O'Reilly et al. (1987) found that the nanoplankton accounted for $49 \%$ of the annual particulate carbon production above $60 \mathrm{~m}$ while it rose to $64 \%$ between 60 and $100 \mathrm{~m}$ and $79 \%$ between 100 and $200 \mathrm{~m}$. Several species show decreased abundance in this deep facies (Arctica islandica, Echinarachnius parma, anthozoans, Pagurus acadianus, P. arcuatus, Buccinum undatum, Cerastoderma pinnulatum, Strongylocentrotus droebachiensis, Anomia spp.), which may relate to lower depth limits. Opposite trends are shown by Dentalium entale, Phascolion strombi, Lumbrinereis fragilis, tubiferous polychaetes and deepwater species (Cancer borealis, Leptasterias tenera, Aporrhais occidentalis). Depth-related distribution patterns agree with previous results on $A$. islandica, $C$. pinnulatum (Theroux \& Wigley 1983, Maurer \& Wigley 1984), E. parma (Maurer \& Wigley 1984, Lawrence et al. 1985, Maciolek \& Grassle 1987, Theroux \& Grosslein 1987) and L. tenera (Franz et al. 1981, Maciolek \& Grassle 1987). Ranking of Aglaophamus circinata and Dichelopandalus leptocerus among the top 30 species (density) indicates increased fine-grain sediments in the deeper stations (Wigley 1968, Maurer \& Leathem 1980, Maurer \& Wigley 1984, Theroux \& Grosslein 1987). The southern limit of the study area corresponds to the southward extension limit of the sand-shell assemblage: A. circinata is a common member of the Southern Georges assemblage (fine sand bottoms) extending to the southern and southwestern flanks of the Bank at depths ranging from 80 to $200 \mathrm{~m}$ (Theroux \& Grosslein 1987).

The sand dunes facies $(F)$ is located in the centralwest between 60 and 70 to $75 \mathrm{~m}$. Sand waves (up to $8 \mathrm{~m}$ high; Fader, in Lough et al. 1989) and megaripples are formed of well-sorted medium-to-coarse sand with few shells (98 to $99 \%$ sand in dune crests; Lough et al. 1989). The megafauna, dominated by Astarte castanea and Echinarachnius parma (Table 7), is an impoverished one with low species diversity and abundance caused by limiting current-sediment erosion conditions (Wildish et al. 1989). Sand waves and megaripples are present where surface tidal currents are more than $40 \mathrm{~cm} \mathrm{~s}^{-1}$ on the Bank (Twichell et al. 1987), which agrees with Greenberg's (1983) model predicting increased tidal currents in the facies area (Fig. 12B). Epibenthic sessile taxa are restricted to few 
individuals of Actinothoe gracillima, Anomia spp., Crenella glandula and Potamilla reniformis. Several major components of the sand-shell assemblage are missing, such as Arctica islandica, Epizoanthus incrustatus, Clymenella torquata, Placopecten magellanicus, Dentalium entale and some predators (Lunatia heros, Hyas coarctatus, Pagurus pubescens, Colus pygmaeus).

In summary, well-defined zonation patterns of benthic megainvertebrates occur on Georges Bank scallop grounds, in relation to environmental conditions. Results agree with previous studies dealing with Georges Bank macrofauna and allow the inclusion of megainvertebrates within the faunal assemblages of Wigley \& Haynes (1958) and Theroux \& Grosslein (1987). This study shows small-scale variations in megafaunal zonation, apparently linked to spatial variations of environmental factors. These results provide a basis for further investigation into the roles of sediment texture as modified by physical disturbances, and ecological factors such as food availability, competition and predation, on distribution patterns of commercially exploited species like sea scallops and surf clams.

Acknowledgements. We thank Captain P. Antle and the crew of the RV 'E. E. Prince', and C. Dibacco, A. Hennigar, and M Lundy for valuable assistance during the cruise. The manuscript benefited from comments by C. Hudon and D. Peer

\section{LITERATURE CITED}

Aldred, R. G., Thurston, M. H., Rick, A. L., Morley, D. R. (1976). An acoustically monitored opening and closing epibenthic sledge. Deep Sea Res. 23: 167-174

Benzecri, J. P. (1973). L'analyse des données. Tome I: La taxinomie. Tome II: L'analyse des correspondances. Dunod, Paris, p. 615, 619

Benzecri, J. P., Benzecri, F. (1984). La pratique de l'analyse des données. I - Analyse des correspondances et classification: exposé élémentaire, 2nd edn. Dunod, Paris, p. 456

Boesch, D. J., Kraeuter, J. N., Serafy, D. K. (1977). Benthic ecological studies: megabenthos and macrobenthos. In: Middle Atlantic outer continental shelf environmental studies. Rep. to Bureau of Land Management, Chap. 6. U.S. Dept. of the Interior, New York OCS Office, New York, p. 111

Buchanan, J. B., Kain, J. M. (1971). Measurement of the physical and chemical enviromment. In: Holme, N. A. McIntyre, A. D. (eds.) Methods for the study of marine benthos. Burgess \& Son, Abingdon, IBP Handbook 16, p. $30-58$

Butman, B., Beardsley, R. C. (1987). Physical oceanography. In: Backus, R. H., Boume. D. W. (eds.) Georges Bank. MIT Press, Cambridge, p. 88-98

Butman, B., Loder, J. W., Beardsley, R. C. (1987). The seasonal mean circulation: observation and theory. In: Backus, $R$. H., Bourne, D. W. (eds.) Georges Bank. MIT Press, Cambridge, p. $125-138$

Caddy, J. F. (1970). A method of surveying scallop populations from a submersible. J. Fish. Res. Bd Can, 27: 535-549

Caddy, J. F. (1973). Underwater observations on tracks of dredges and trawls and some effects of dredging on a scallop ground. J. Fish. Res. Bd Can. 30: 173-180

Caddy, J. F. (1976). Practical considerations for quantitative estimation of benthos from a submersible. In: Drew, A., Lythgoe, J. N., Woods, J. D (eds.) Underwater research. Academic Press, New York, p. 285-298

Caddy, J. F., Carter, J. A. (1984). Macro-epifauna of the lower Bay of Fundy. Observations from a submersible and analysis of faunal adjacencies. Can. J. Fish. Aquat. Sci., Tech. Rep. 1254: p. 35

Cohen, E. B., Grosslein, M. D. (1987). Production on Georges Bank compared with other shelf ecosystems. In: Backus, R. H., Bourne. D. W. (eds.) Georges Bank. MIT Press, Cambridge, p. 383-391

Cohen, E. B., Grosslein, M. D., Sissenwine, M. P., Steimle, F. W., Wright, W. R. (1982). An energy budget of Georges Bank. In: Mercer, M. C. (ed.) Multi-species approaches to fisheries management advice. Can. Spec. Pub. Fish. Aquat. Sci. 59: 95-107

Cummins, R. Jr (1971). Calico scallops of the southeastern United States, 1959-1969, National Oceanic and Atmospheric Administration Tech. Rep., National Marine Fisheries Service Spec. Sci. Rep. Fish. 627: p. 22

Cura, J. J. Jr (1987). Phytoplankton. In: Backus, R. H., Bourne, D. W. (eds.) Georges Bank. MIT Press, Cambridge, p. 213-218

Daget, J. (1976). Les modèles mathématiques en écologie. Masson, Paris, Coll. Ecologie 8, p. 172

Dare, J. (1987). Settlement of scallop Pecten maximus (L.) spat on natural substrates off south-west England: the hydroid connection. In: Beaumont, A.R. (ed.) 6th Int. Pectinid workshop. Menai Bridge. School of Ocean Sciences, Menai Bridge, p. 27 (mimeo)

Dickinson, J. J., Wigley, R. L. (1981). Distribution of gammaridean Amphipoda (Crustacea) on Georges Bank. National Oceanic and Atmospheric Administration Tech. Rep., National Mar. Fish. Serv. Spec. Sci. Rep. Fish. 746: p. 25

Edwards, R. L., Bowman, R. E. (1979). Food consumed by continental shelf fish. In: Clepped, H. (ed.) Predator-prey systems in fishery management. Sport Fishing Institute, Washington, D.C., p. $387-406$

Flagg, C. N. (1987). Hydrographic structure and variability. In: Backus, R. H., Bourne, D. W. (eds.) Georges Bank. MIT Press, Cambridge, p. 108-124

Franklin, A., Pickett, G. D., Holme, N. A., Barrett, R. L. (1980). Surveying stocks of scallops (Pecten maximus) and queens (Chlamys opercularis) with underwater television. J. mar. biol. Ass. U.K. 60: 181-191

Franz, D. R., Worley, E. K., Merrill, A. S. (1981). Distribution patterns of common seastars of the Middle Atlantic Continental shelf of the Northwest Atlantic (Gulf of Maine to Cape Hatteras). Biol. Bull. mar. biol. Lab., Woods Hole 160 : $394-418$

Frontier, S. (1983). Stratégie d'échantillonnage en écologie Masson, Paris, Coll. Ecologie 17, p. 494

Gauch, H. G. Jr, Whittaker, R. H., Wentworth, T R. (1977). A comparative study of reciprocal averaging and other ordination techniques. J. Ecol. 65: 157-174

Greenberg, D. A. (1983). Modeling the mean barotropic circulation in the Bay of Fundy and Gulf of Maine. J. phys Oceanogr. 13 (5): 886-904

Grosslein, M. D., Brown, B. E., Hennemuth, R. C. (1979) Research, assessment and management of a marine ecosystem in the northwest Atlantic, a case study. In: Cairns, J. Jr, Patil, G. P., Waters, W E. (eds.) Environmental biomonitoring, assessment, prediction, and management: certain case studies and related quantitative 
issues. International Cooperative Publishing House, Fairland, p. 289-35?

Guttman, L. (1941). The quantification of a class of attributes: a theory and method of a scale construction. In: Horst, P. (ed.) The prediction of personal adjustment. Soc. Sci. Res. Counc., New York, p. 321-348

Hill, M. O. (1973). Reciprocal averaging: an elgenvector method of ordination. J. Ecol. 61.237-249

Hill, M. O. (1974). Correspondence analysis: a neglected multivariate method. Appl. Statist. 23: 340-354

Hily, C. (1989). La mégafaune benthique des fonds meubles de la rade de Brest: pré-échantillonnage par vidéo sousmarine. Cah. Biol. mar. 30: 433-454

Holme, N. A. (1971). Macrofauna sampling. In: Holme, N. A., McIntyre, A. D (eds.) Methods for the study of marine benthos. Blackwell Scientific Pub., Oxford \& Edinburgh, IBP Handbook 16, p. 80-130

Hulsemann, J. (1967). The continental margin off the Atlantic coast of the United States: carbonate in sediments, Nova Scotia to Hudson Canyon. Sedimentology 8: 121-145

Langton, R. W., Robinson, W. E. (1990). Faunal associations on scallop grounds in the western Gulf of Maine. J. exp. mar. Biol. Ecol. 144: 157-171

Lawrence, P., Strong, K. W., Pocklington, P., Stewart, P. L., Fader, G. B. (1985). A photographic atlas of the eastern Canadian continental shelf: Scotian Shelf and Grand Banks of Newfoundland. Geol. survey open file 2054, Maritime Testing Ltd, Dartmouth, Nova Scotia, p. 185

Lebart, L., Morineau, A., Fénelon, J. P. (1982). Traitement des données statistiques. Méthodes et programmes. Dunod, Paris, p. 510

Le Bris, H. (1988). Fonctionnement des écosystèmes benthiques côtiers au contact d'estuaires: la rade de Lorient et la baie de Vilaine. Thèse doc., Univ. Bretagne Occidentale, Brest

Legendre, L., Legendre, P. (1984a). Ecologie numérique. Tome I: Le traitement multiple des données écologiques. Masson, Paris, Coll. Ecologie 12, p. 260

Legendre, L., Legendre, P. (1984b). Ecologie numérique. Tome II: La structure des données écologiques. Masson, Paris, Coll. Ecologie 13, p. 335

Lough, R. G., Trites, R. W. (1989). Chaetognaths and oceanography on Georges Bank. J. mar Res. 47: 343-369

Lough, R. G., Valentine, P. C., Potter, D. C., Auditore, P. J., Bolz, G. R., Neilson, J. D., Perry, R. I. (1989). Ecology and distribution of juvenile cod and haddock in relation to sediment type and bottoms currents on eastern Georges Bank. Mar Ecol. Prog. Ser. 56: 1-12

Maciolek, N. J., Grassle, J. F. (1987). Variability of the benthic fauna. II. The seasonal variation 1981-82. In: Backus, R. H., Bourne, D. W. (eds.) Georges Bank. MIT Press, Cambridge, p. 303-309

Maciolek, N. J., Grassle, J. F., Hecker, B., Brown, B., Blake, J. A., Boehm, P. D., Petrecca, R., Duffy, S., Baptiste, E., Ruff, R. E. (1987). Study of biological processes on the U.S. North Atlantic Slope and Rise. OCS study, U.S. Dept Interior, Minerals Management Service 87-0051, 2 vol.: Exec. Sum. p. 41, Final Rep., p. 357

Maurer, D. (1983). Review of benthic invertebrates of Georges Bank in relation to gas and oil exploration with emphasis on management implications. National Marine Fisheries Service, Northeast Fisheries Center, Woods Hole, Massachusetts, Lab. Ref. Doc. 83-16, p. 329

Maurer, D., Leathem, W. (1980). Dominant species of polychaetous annelids of Georges Bank. Mar. Ecol. Prog. Ser. 3: 135-144

Maurer, D., Leathem, W. (1981a). Ecological distribution of polychaetous annelids from the New England Shelf, Georges Bank. Int. Rev. ges. Hydrobiol 66 (4): 505-528

Maurer, D., Leathem, W. (1981b). Polychaete feeding guilds from Georges Bank, USA. Mar Biol. 62: 161-171

Maurer, D., Wigley, R. L. (1984). Biomass and density of macrobenthic invertebrates on the U.S. Continental Shelf off Martha's Vineyard, Mass, in relation to environmental factors. National Oceanic and Atmospheric Administration Tech. Rep., National Marine Fisheries Service Spec. Sci. Rep. Fish. 783, p. 20

Mcintyre, A. D. (1971). Efficiency of benthos sampling gear In: Holme, N. A., McIntyre, A. D. (eds.) Methods for the study of marine benthos. Blackwell Scientific Pub., Oxford \& Edinburgh, IBP Handbook 16, p. 140-146

Michael, A. D. (1987). Variability of the benthic fauna. I. The New England outer continental shelf. Environmental Benchmark program 1977. In: Backus, R. H., Bourne, D. W (eds.) Georges Bank. MIT Press, Cambridge, p. 296-302

Michael, A. D., Long, C. D., Maurer, D., McGrath, R. (1983). Georges Bank benthic infauna historical study. Final Rep. to U.S. Dept of the Interior, Minerals Management Service, Washington, D.C., p. 171

Mills, E. L., Pittman, K., Munroe, B. (1982). Effects of preservation on the weight of marine benthic invertebrates. Can. J. Fish. Aquat. Sci. 39: 221-224

Mohn, R. K., Robert, G., Roddick, D. L. (1988). Georges Bank scallop stock assessment - 1987 Can. Atl. Fish. Sci. Adv. Comm. (CAFSAC) Res. Doc $88 / 3$, p. 29

Moody, J. A., Butman, B., Beardsley, R. C., Boicourt, W., Brown. W. S., Daifuku, P., Irish, J. D., Mayer, D. A., Mofjeld, H. O., Petrie, B., Ramp, S., Smith, P., Wright, W. R. (1984). Atlas of tidal elevation and current observations on the Northeast American continental shelf and slope. U.S. Geol. Survey Bull. 1611, p. 122

Neff, J. M. (1987). The potential effects of drilling effluents on marine organisms on Georges Bank. In: Backus, R. H., Boume, D. W (eds.) Georges Bank. MIT Press, Cambridge, p. 531-539

Ogden, J. C. (1980). Faunal relationships in Caribbean seagrass beds. In: Phillips, R. C., McRoy, C. P. (eds.) Handbook of seagrass biology. An ecosystem perspective. Garland STPM Press, New York, p. 173-198

Ojeda, F. P., Dearborn, J. H. (1989). Community structure of macroinvertebrates inhabiting the rocky subtidal zone in the Gulf of Maine: seasonal and bathymetric distribution. Mar. Ecol. Prog. Ser 57: 147-161

O'Reilly, J. E., Evans-Zetlin, C., Busch, D. A. (1987). Primary production. In: Backus, R. H., Bourne, D. W. (eds.) Georges Bank. MIT Press, Cambridge, p. 220-233

Parsons, T. R., Takahashi, M., Hargrave, B. (1977). Benthic communities. In: Parsons, T R., Takahashi, M., Hargrave, B. (eds.) Biological oceanographic processes, 2nd edn. Pergamon Press, New York, p. 176-264

Pielou, E. C. (1966). Shannon's formula as a measure of specific diversity: its use and measure. Am. Nat. 100: $463-465$

Robert, G., Black, G. A. P. (1990). Georges Bank scallop stock assessment - 1989. Can. Atl. Fish. Sci. Adv. Comm. (CAFSAC) Res. Doc. $90 / 19$, p. 30

Schlee, J. S. (1973). Atlantic continental shelf and slope of the United States; sediment texture of the northeastern part. U.S. Dept of the Interior, Geological Survey, Prof. paper 529-L, p. 64

Schlee, J. S., Pratt, R. M. (1970). Atlantic continental shelf and slope of the United States; gravels of the northeastern part. U.S. Dept of the Interior, Geological Survey, Prof paper $529-$ H. p. 39 
Sokal, R. R, Rohlf, F. J. (1981). Biometry, 2nd edn. W. H. Freeman, San Francisco

Steimle, F. W. (1987). Production of the benthic fauna. In: Backus, R. H., Bourne, D. W (eds.) Georges Bank. MIT Press, Cambridge, p. 310-314

Theroux, R. B., Grosslein, M. D. (1987). Benthic fauna. In Backus, R. H., Bourne, D. W (eds.) Georges Bank. MIT Press, Cambridge, p. 283-295

Theroux, R. B., Wigley, R. L. (1983). Distribution and abundance of East coast bivalve mollusks based on specimens in the Northeast Fisheries Center Specimen Reference Collection, Woods Hole, Massachusetts. National Oceanic and Atmospheric Administration Tech. Rep., National Marine Fisheries Service Spec. Sci. Rep. Fish. 768 , p. 172

Thouzeau, G. (1989). Déterminisme du pré-recrutement de Pecten maximus (L.) en baie de Saint-Brieuc. Thèse doc. Université Bretagne Occidentale, Brest

Thouzeau, G., Lehay, D. (1988). Variabilité spatio-temporelle de la distribution, de la croissance et de la survie des juvéniles de Pecten maximus (L.) issus des pontes de 1985 en baie de Saint-Brieuc. Oceanol. Acta 11 (3): 267-284

Thouzeau, G., Robert, G., Smith, S. J. (1991). Spatial variability of the distribution and growth of juvenile and adult sea scallops Placopecten magellanicus on eastern Georges Bank (Northwest Atlantic). Mar. Ecol. Prog. Ser. (in press)

Thouzeau, G., Vine, $R$. (in press). L'échantillonnage du mégabenthos en zone hauturière: technique développée sur le Georges Bank (Atlantique nord-ouest). C. r. Acad Sci., Paris, série III

Twichell, D. C. (1983). Bedform distribution and inferred sand transport on Georges Bank, United States Atlantic Continental Shelf. Sedimentology 30: 695-710

Twichell, D. C., Butman, B., Lewis, R. S. (1987). Shallow structure, surficial geology and the processes currently shaping the Bank. In: Backus, R. H., Bourne, D. W. (eds.) Georges Bank. MIT Press, Cambridge, p. 31-37

Watson, G. F., Robertson, A. I., Littlejohn, M. J. (1984). Invertebrate macrobenthos of the seagrass communities in Western Port, Victoria. Aquat. Bot. 18: 175-197

Wigley, R. L. (1960). Note on the distribution of Pandalidae

This article was presented by G. C. Harding, Dartmouth, N.S., Canada
(Crustacea, Decapoda) in New England waters. Ecology 41 (3): $564-570$

Wigley, R. L. (1961a). Bottom sediments of Georges Bank. J. sedim. Petrol. 31 (2): 165-188

Wigley, R. L. (1961b). Benthic fauna of Georges Bank. In: Transactions of the 26th North American Wildlife and Natural Resources Conference, March 6, 7, and 8, 1961, p. 310-317

Wigley, R. L. (1965). Density-dependent food relationships with reference to New England groundfish. International Commission for the Northwest Atlantic Fisheries (ICNAF), Spec. Pub. 6, p. 501-513

Wigley, R. L. (1968). Benthic invertebrates of the New England fishing banks. Underwater Nat. 5 (1): 8-13

Wigley, R. L., Haynes, E. B. (1958). Bottom ecology. In: Annual Rep., U.S. Dept of the Interior, Fish and Wildlife Service, Woods Hole Laboratory, Mass., p. 55-58

Wigley, R. L., Theroux, R. B. (1965). Seasonal food habits of Highlands ground haddock. Trans. Am. Fish. Soc. 94 (3): 243-251

Wigley, R. L., Theroux, R. B. (1976). Macrobenthic invertebrate fauna of the Middle Atlantic Bight region. Part II: Faunal composition and quantitative distribution. Northeast Fisheries Center, National Marine Fisheries Service Rep., Woods Hole, Massachusetts, p. 395

Wigley, R. L., Theroux, R. B. (1981). Atlantic Continental Shelf and Slope of the United States. Macrobenthic invertebrate fauna of the Middle Atlantic Bight region. Faunal composition and quantitative distribution. U.S. Dept of the Interior, Geological Survey, Prof. paper 529-N, p. 198

Wildish, D. J., Wilson, A. J., Frost, B. (1989). Benthic macrofaunal production of Browns Bank, Northwest Atlantic. Can. J. Fish. Aquat. Sci. 46: 584-590

Williams, A. B., Wigley, R. L. (1977). Distribution of decapod Crustacea off northeastern United States based on the Northeast Fisheries Center Specimen Reference Collection, Woods Hole, Massachusetts. National Oceanic and Atmospheric Administration, National Marine Fisheries Service circular 407, p. 44

Zeitzschel, B. (1980). Sediment-water interactions in nutrient dynamics. In: Tenore, K. R., Coull, B. C. (eds.) Marine benthic dynamics. Belle W Baruch Symp. Mar. Sci. 11, Univ. of South Carolina Press, Columbia, p. 195-218

Manuscript first received: January 10, 1991

Revised version accepted: May 17, 1991 